\title{
A tyrosyl-tRNA synthetase binds specifically to the group I intron catalytic core
}

\author{
Qingbin Guo and Alan M. Lambowitz ${ }^{1}$
}

Departments of Molecular Genetics and Biochemistry and the Biotechnology Center, The Ohio State University, Columbus, Ohio 43210 USA

\begin{abstract}
The Neurospora CYT-18 protein, the mitochondrial tyrosyl-tRNA synthetase, functions in splicing group I introns in mitochondria. Here, we show that CYT-18 binds strongly to diverse group I introns that have minimal sequence homology and recognizes highly conserved structural features of the catalytic core of these introns. Inhibition experiments indicate that the intron RNA and RNA $^{\mathrm{Tyr}}$ compete for the same or overlapping binding sites in the CYT-18 protein. Considered together with functional analysis, our results indicate that the CYT-18 protein promotes splicing by binding to the intron core and stabilizing it in a conformation required for catalytic activity. Furthermore, the specific binding of the synthetase suggests that the group I intron catalytic core has structural similarities to tRNAs, which could reflect either convergent evolution or an evolutionary relationship between group I introns and tRNAs.
\end{abstract}

[Key Words: Catalytic RNA; group I intron; RNA splicing; aminoacyl-tRNA synthetase; mitochondrial RNA processing]

Received April 14, 1992; revised version accepted June 1, 1992.

Although group I introns use RNA-catalyzed splicing reactions, many, if not all, require proteins for efficient splicing in vivo (for review, see Lambowitz and Perlman 1990). In the case of mitochondrial RNA splicing, these proteins have been shown to include maturases encoded within some group I introns, as well as a variety of splicing factors encoded by host chromosomal genes. The latter tend to differ between Neurospora and yeast, and they include aminoacyl-tRNA synthetases and other cellular RNA-binding proteins that have an additional function in their host cell. We suggested that host proteins that have already differentiated may have adapted to function in splicing relatively recently in evolution by taking advantage of their ability to recognize structural features of group I introns resembling those in their normal cellular RNA targets (Lambowitz and Perlman 1990). Most host-encoded splicing factors function in splicing one or a small number of related group I introns. However, the Neurospora CYT-18 protein, the mitochondrial tyrosyl-tRNA synthetase (mt TyrRS), functions in splicing a number of different group I introns in mitochondria and presumably recognizes conserved structural features of these introns (Collins and Lambowitz 1985). The fact that the CYT-18 protein is an aminoacyl-tRNA synthetase raises the possibility that

${ }^{1}$ Corresponding author. these structural features resemble those found in tRNAs (Akins and Lambowitz 1987).

To investigate how the Neurospora mt TyrRS functions in splicing, we developed an in vitro-splicing system based on the ability of the protein to splice the Neurospora mitochondrial large rRNA (mt large rRNA) intron, which is not self-splicing under any conditions examined (Garriga and Lambowitz 1986). Studies using this in vitro system showed that splicing occurs by the same guanosine-initiated transesterification reactions used by self-splicing group I introns and remains dependent on the integrity of the group I intron catalytic core (Guo et al. 1991). Furthermore, mutant CYT-18 proteins, with linker insertions near the predicted ATP-binding site, have little, if any, tyrosyl-adenylation activity but retain substantial splicing activity, indicating that the normal catalytic activity of the protein is not required for splicing (Kittle et al. 1991; G. Mohr, A. Cherniack, G. Guo, J. Gianelos, and A.M. Lambowitz, unpubl.). Together, these findings indicate that the splicing reaction remains essentially RNA catalyzed and that the ability of the protein to function in splicing requires only that it binds to the precursor RNA.

Regions of the CYT-18 protein required for splicing have been identified by analyzing mutant and partial revertant alleles of the cyt-18 gene, as well as in vitro mutants of the CYT-18 protein synthesized in Escherichia coli. These regions include a small, idiosyncratic amino- 
terminal domain not found in other TyrRSs that do not function in splicing, parts of the nucleotide binding fold, and the putative tRNA-binding domain toward the carboxyl terminus of the protein (Cherniack et al. 1990; Kittle et al. 1991). A number of mutations in the carboxy-terminal domain result in parallel inhibition of splicing and TyrRS activity, suggesting that this region may be involved in binding both the intron and tRNA substrates. Deletions in the idiosyncratic amino-terminal domain inhibit splicing activity of the CYT-18 protein but leave substantial TyrRS activity assayed with $E$. coli tRNA ${ }^{\mathrm{Tyr}}$. However, recent experiments have shown that part of the idiosyncratic domain is required for efficient aminoacylation of the Neurospora mitochondrial tRNA $^{\text {Tyr }}\left(m t\right.$ tRNA $\left.{ }^{\text {Tyr }}\right)$, suggesting that it interacts with some feature of this tRNA not found in the $E$. coli tRNA $^{\text {Tyr }}$ (Cherniack 1991). The finding that different regions of the CYT-18 protein required for splicing may also be involved in binding the tRNA suggests that similar interactions may be used for the binding of both the intron and tRNA substrates.

To facilitate studies on the interaction between the CYT-18 protein and the intron RNA, we constructed a mini-intron of 388 nucleotides, compared with $2.3 \mathrm{~kb}$ for the original intron, that is still spliced in a protein-dependent manner (Guo et al. 1991). Experiments with mutant derivatives of this mini-intron suggested that the inability of the Neurospora intron to self-splice reflects instability of a structure in the intron core or in the interaction between the core and the P1 stem containing the 5' splice site (Guo et al. 1991). In reverse splicing catalyzed by the CYT- 18 protein, the protein appears to bind to the free intron to form an active ribonucleoprotein (RNP) complex, which then binds ligated exon RNA (Mohr and Lambowitz 1991). Finally, recent experiments have shown that the CYT- 18 protein can suppress structural defects in the catalytic core of mutant bacteriophage T4 $t d$ or yeast $\omega^{+}$introns (Mohr et al. 1992). Together, these findings suggest that the CYT-18 protein promotes splicing by binding to the intron and facilitating formation of the catalytically active structure of the intron core. Similarly, the yeast CBP2 protein, a group I intron splicing factor specific for $c o b$ intron 5 , has been shown to require an intact catalytic core for binding, indicating either that the protein binds to the core or that the core is required for proper display of sequences that bind the protein (Gampel and Cech 1991).

The precise identification of the CYT-18 protein-binding site in the intron RNA is the key to understanding how the protein functions in splicing and its evolutionary significance. Here, we show that the CYT-18 protein binds strongly to a number of different group I introns, and we localized the CYT-18 binding site in the Neurospora mt large rRNA intron to a highly conserved region of the catalytic core. Considered together with recent functional analysis (Mohr et al. 1992), our results indicate that the CYT-18 protein promotes splicing by binding to the intron core and stabilizing it in the catalytically active conformation. Furthermore, our results suggest that the group I intron catalytic core, which is specifically recognized by the synthetase, has structural features that resemble those in tRNAs.

\section{Results}

Binding of the CYT-18 protein to the Neurospora mt large rRNA intron

Table 1 summarizes intron constructs used in the present work, and Figure 1 shows the 388-nucleotidederivative of the Neurospora mt large rRNA intron (pBD5A) used as the starting point for this study. This intron was constructed by deleting sequences corresponding to the open reading frame (ORF), which is ordinarily encoded in the intron, as well as nonessential parts of P2 and L8. We showed that splicing of this 388nucleotide intron is completely dependent on the CYT18 protein (Guo et al. 1991).

In initial experiments we used the nitrocellulose filterbinding method to assay the binding of purified CYT- 18 protein to a 503-nucleotide in vitro transcript containing the 388-nucleotide intron. In these experiments, low concentrations of ${ }^{32} \mathrm{P}$-labeled in vitro transcript were incubated with increasing concentrations of purified CYT18 protein, and binding was assayed by retention of the ${ }^{32}$ P-labeled RNA on a nitrocellulose filter. As shown in Figure $2 \mathrm{~A}$, the CYT-18 protein bound strongly to the transcript containing the intron (pBD5A/BanI), whereas control transcripts (pHX11/PvuII and pBD5A/NheI)

Table 1. Plasmids for synthesis of in vitro transcripts containing the Neurospora mt large rRNA intron and derivatives

\begin{tabular}{|c|c|}
\hline Plasmid/enzyme & In vitro transcript ${ }^{a}$ \\
\hline pHX11/BanI & $\begin{array}{l}\text { Nc mt large rRNA intron: 5'E/I/3'E, } \\
844 / 2296 / 50 \mathrm{nt}\end{array}$ \\
\hline pHX9422/BanI & $\begin{array}{l}\text { Nc mt large rRNA intron: } 5^{\prime} \mathrm{E} / \mathrm{I} / 3^{\prime} \mathrm{E}, \\
65 / 583 / 50 \mathrm{nt}\end{array}$ \\
\hline pBD5A/BanI & $\begin{array}{l}\text { Nc mt large rRNA intron: } 5^{\prime} \mathrm{E} / \mathrm{I} / 3^{\prime} \mathrm{E}, \\
65 / 388 / 50 \mathrm{nt}\end{array}$ \\
\hline pL95/BanI & pBD5A: $5^{\prime}$ truncation to $\mathrm{J} 2 / 3$ (nt 95 ) \\
\hline $\mathrm{pL} 97 /$ BanI & pBD5A: 5' truncation to $\mathrm{P3}$ (nt 97) \\
\hline $\mathrm{pL} 107 /$ BanI & pBD5A: $5^{\prime}$ truncation to $\mathrm{P} 4$ (nt 107 ) \\
\hline pL129/BanI & pBD5A: $5^{\prime}$ truncation to P5 (nt 129) \\
\hline $\mathrm{pR} 367 / \mathrm{BamHI}$ & pBD5A: $3^{\prime}$ truncation to $P 9.1$ (nt 367 ) \\
\hline pR359/EcoRI & pBD5A: 3' truncation to $\mathrm{P9}$ (nt 359) \\
\hline pR342/BamHI & pBD5A: $3^{\prime}$ truncation to $\mathrm{J} 7 / 9$ (nt 342 ) \\
\hline $\mathrm{pR} 312 / \mathrm{NcoI}$ & pBD5A: $3^{\prime}$ truncation to $\mathrm{L} 8$ (nt 312 ) \\
\hline pR243/BamHI & pBD5A: $3^{\prime}$ truncation to $\mathrm{J} 6 / 7$ (nt 243 ) \\
\hline $\mathrm{pR} 239 / \mathrm{BamHI}$ & pBD5A: $3^{\prime}$ truncation to $\mathrm{P} 6$ (nt 239 ) \\
\hline $\mathrm{pR} 175 /$ NheI & pBD5A: $3^{\prime}$ truncation to $\mathrm{P} 6 \mathrm{~b}$ (nt 175$)$ \\
\hline $\mathrm{p} \Delta 108-139 / B a n I$ & pBD5A: $\triangle \mathrm{P} 4-\mathrm{P} 5$ \\
\hline $\mathrm{p} \Delta 115-133 /$ BanI & pBD5A: $\triangle$ P5 \\
\hline $\mathrm{p} \Delta \mathrm{l} 49-233 / B a n I$ & pBD5A: $\triangle \mathrm{P} 6 \mathrm{a}-\mathrm{P} 6 \mathrm{~b}$ \\
\hline $\mathrm{p} \Delta 155-224 / B a n I$ & pBD5A: $\triangle \mathrm{L} 6 \mathrm{a}-\mathrm{P} 6 \mathrm{~b}$ \\
\hline $\mathrm{p} \Delta 252-282 / B a n I$ & pBD5A: $\triangle \mathrm{P} 7.1-\mathrm{P} 7.2$ \\
\hline $\mathrm{p} \Delta 258-323 /$ BamHI & pBD5A: $3^{\prime}$ truncation to $\mathrm{P} 7.1$ (nt 258 ) \\
\hline $\mathrm{p} \Delta 258-323 / B a n I$ & pBD5A: $\Delta \mathrm{P} 8$ \\
\hline $\mathrm{pI} 75 / \mathrm{BamHI}$ & $\begin{array}{l}\text { RNA containing } 75 \mathrm{nt} \text { of } \mathrm{P} 4-\mathrm{P} 5-\mathrm{P} 6 \\
\text { with sequences distal to } \mathrm{P} 6 \mathrm{a} \text { deleted }\end{array}$ \\
\hline
\end{tabular}

${ }^{a}$ (Nc) Neurospora crassa; (nt) nucleotide. 


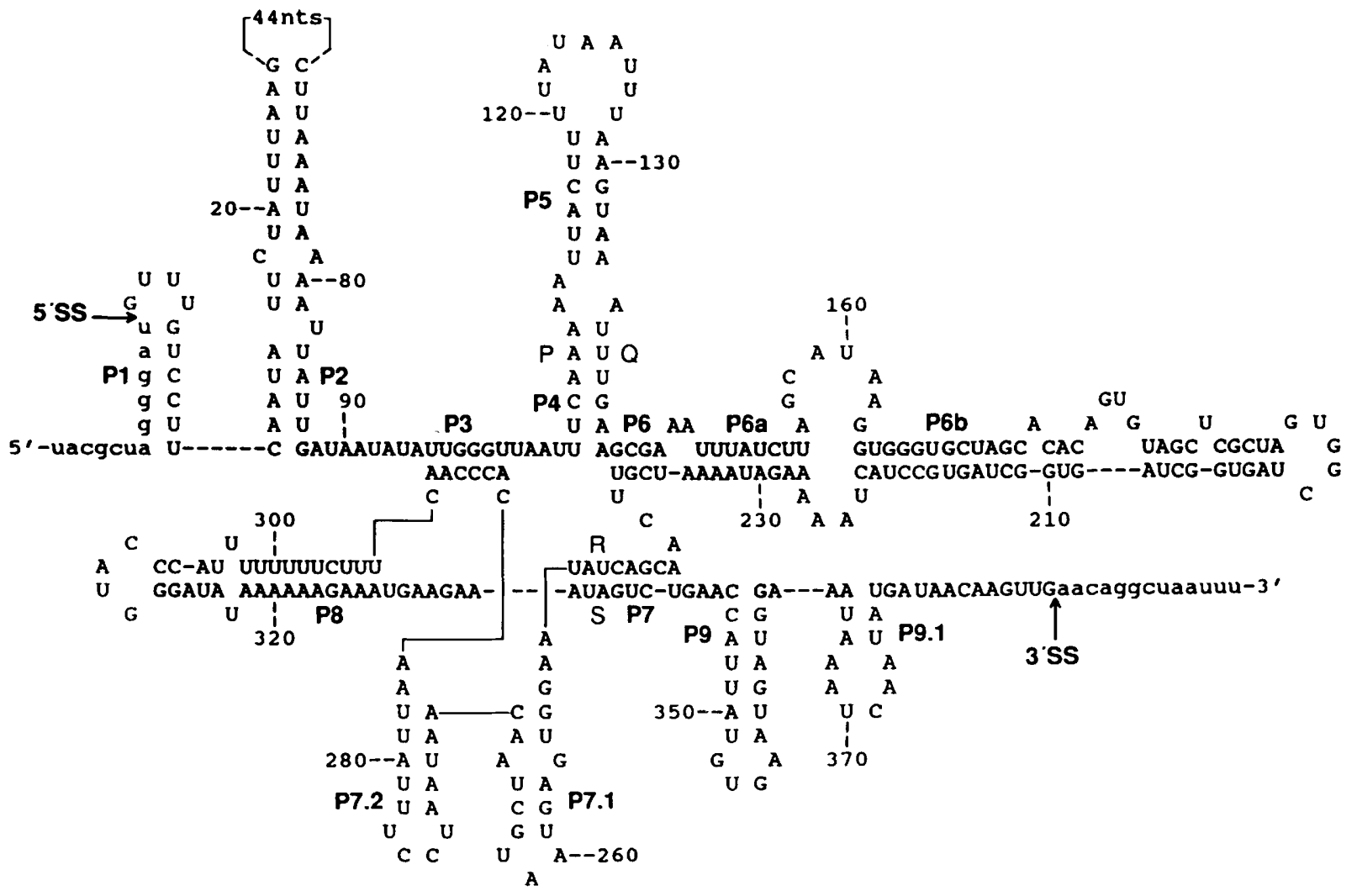

Figure 1. Predicted secondary structure of the 388-nucleotide derivative of the Neurospora mt large rRNA intron. The intron is cloned in pBD5A. Uppercase letters indicate intron sequences; lowercase letters indicate exon sequences. (5' $\left.\mathrm{SS}, 3^{\prime} \mathrm{SS}\right) 5^{\prime}$ - and $3^{\prime}$-splice sites, respectively.

showed only weaker binding at higher protein concentrations. Figure $2 \mathrm{~B}$ shows that specific binding of the CYT-18 protein to the transcript containing the intron was competed efficiently by the same transcript (pBD5A/BanI) but not by control transcripts (pHX11/ PvuII or pBTC20/KpnI). Based on 11 nitrocellulose filterbinding experiments, like that in Figure 2A, we calculated that the CYT-18 protein binds to the intron with a $K_{\mathrm{d}}$ of $6 \pm 2 \mathrm{~nm}$. The $K_{\mathrm{d}}$ value was not affected by the presence of 0.2 or $0.5 \mathrm{~mm}$ GTP (not shown) and is essentially the same as that for the excised intron RNA 15.5 $\mathrm{nM}$ corrected for the proportion of active CYT-18 protein; Mohr and Lambowitz 1991). UV-cross-linking experiments confirmed that the CYT- 18 protein is in direct contact with the intron RNA in the complex (Guo 1992).

The stoichiometry of the intron-protein complex was determined by using a protein concentration near the $K_{\mathrm{d}}$ and varying the RNA concentration by two orders of magnitude above and below the $K_{\mathrm{d}}$. As shown in Figure $2 \mathrm{C}$, a double-reciprocal plot of the binding data gave a straight line with a $y$-intercept close to one (1.16), indicating that there is one RNA-binding site per CYT-18 protein dimer. From the slope of the line in Figure $2 \mathrm{C}$, we calculated a $K_{\mathrm{d}}$ of $7.8 \pm 0.7 \mathrm{nM}$, in good agreement with the $K_{\mathrm{d}}$ measured by varying the protein concentration.

\section{Binding of the CYT-18 protein to other group I introns}

Additional nitrocellulose filter-binding experiments sum- marized in Table 2 showed that the CYT-18 protein binds strongly to other group I introns, including mitochondrial introns from Neurospora, Podospora, and yeast, as well as the $t d$, sun $Y$, and $n r d B$ introns of bacteriophage $\mathrm{T} 4$. The introns that bind CYT-18 strongly belong to different subclasses and include self-splicing, as well as non-self-splicing, introns. An apparent exception is the Tetrahymena nuclear rRNA intron, but recent studies have shown that CYT-18 binds strongly to a derivative of this intron that lacks the large peripheral structure P5a,b,c, which presumably obscures the CYT18-binding site $\left(K_{\mathrm{d}}=9 \mathrm{nM} ; \mathrm{Q}\right.$. Guo, L. Zhao, and A. Lambowitz, unpubl.). The CYT-18 protein did not bind strongly to group II introns, as expected because it does not function in splicing group II introns/Collins and Lambowitz 1985). The finding that the CYT-18 protein binds strongly to a number of different group I introns suggests that it interacts with conserved structural features of these introns.

Competition between the intron RNA and Neurospora $m t$ tRNA ${ }^{T y r}$ for the CYT-18 protein

We wished to compare the ability of CYT-18 protein to bind group I introns with its ability to bind tRNA ${ }^{\text {Tyr }}$. Because sufficient quantities of Neurospora mt tRNA ${ }^{\text {Tyr }}$ could not be isolated from mitochondria, we constructed a plasmid, pTYR, which enabled us to synthesize large amounts of Neurospora $\mathrm{mt} \mathrm{tRNA}^{\mathrm{Tyr}}$ in vitro from the 


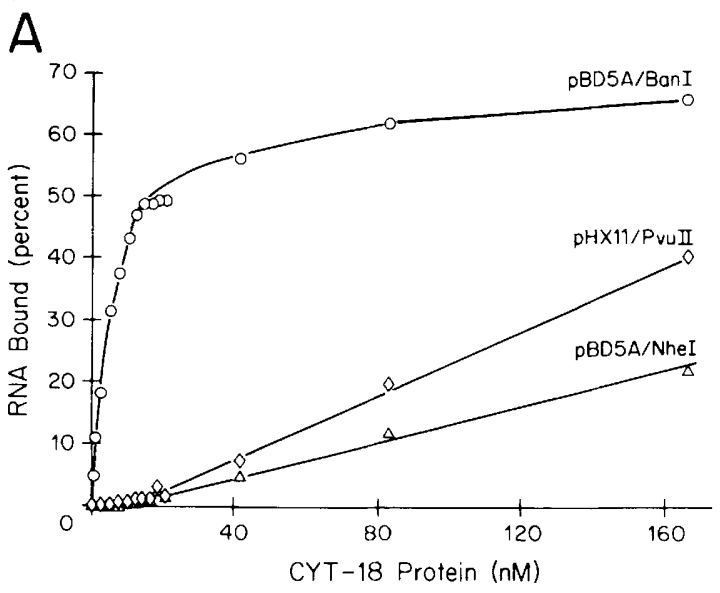

Figure 2. Nitrocellulose filter binding of the CYT-18 protein to the Neurospora mt large $\mathrm{rRNA}$ intron. $(A)$ Binding of CYT-18 protein to the pBD5A/BanI transcript containing the 388-nucleotide derivative of the Neurospora mt large rRNA intron and to nonspecific RNAs (pHXll/PvuII, 171-nucleotide RNA containing 5' exon sequences; pBD5A/NheI, 239-nucleotide RNA containing 65 nucleotides of $5^{\prime}$ exon plus 174 nucleotides of intron truncated in $\mathrm{P} 6 \mathrm{~b}$ ). The percentage of ${ }^{32} \mathrm{P}$-labeled RNA retained on the filter is plotted as a function of concentration of the CYT-18 protein dimer (nM). (B) Binding of the CYT-18 protein to the intron RNA (pBD5A/ $B a n I$ ) competed by the same RNA or nonspecific RNAs [pHXll/PvuII (see above) and $\mathrm{pBTC} 20 / \mathrm{KpnI}$ (869-nucleotide transcript corresponding to the antisense strand of Neurospora nuclear gene cyt-20]. The amount of RNA bound in the presence of the competitor divided by the amount bound in the absence of the competitor $(\theta)$ is plotted as the function of the competitor RNA concentration (nM). (C) Stoichiometry of the complex between the CYT-18 protein and pBD5A/BanI intron RNA. The reciprocal of the fraction of the CYT-18 protein in the complex $(1 / \bar{\nu})$ is plotted against the reciprocal of the concentration of free $\mathrm{RNA}\left[\mathrm{l} /\left(\mathrm{RNA}_{\mathrm{free}}\right), \mathrm{nM}^{-1}\right]$. The amount of bound RNA was corrected for the efficiency of binding (0.64), which was determined from a plot of [RNA bound] (cpm) vs. [total RNA] (cpm) in separate experiments, where an excess of CYT-18 protein $(377 \mathrm{nM})$ was bound to varying amounts of ${ }^{32} \mathrm{P}-\mathrm{labeled}$ RNA from 0.4 to $400 \mathrm{pM}$ (Yarus and Berg 1967). The concentration of free RNA [ RNA $_{\text {free }}$ ] at each point was calculated by subtracting the concentration of bound RNA corrected for efficiency from the total RNA concentration (Yarus and Berg 1967). The data in $C$ are averages for duplicate samples.

phage $\mathrm{T} 3$ promoter. The in vitro transcript lacks modified nucleotides but is still recognized efficiently by the CYT-18 protein (see Materials and methods).

To investigate whether the intron and tRNA bind to similar sites in the CYT-18 protein, we tested their ability to compete for synthetase and splicing activity, respectively. Figure 3 shows that the Neurospora $\mathrm{mt}$ tRNA ${ }^{\text {Tyr }}$ inhibited splicing of the mt large rRNA intron. Although inhibition required a relatively high concentration of the Neurospora mt tRNA ${ }^{\mathrm{Tyr}}(>25 \mu \mathrm{M}$ at 0.11 $\mu \mathrm{M}$ intron RNA; see legend to Fig. 31, this tRNA was nevertheless a better inhibitor of splicing than other tRNAs tested, including $E$. coli tRNA ${ }^{\mathrm{Tyr}}, E$. coli tRNA $^{\text {Val }}$, total E. coli or yeast tRNA, and in vitro-transcribed E. coli or yeast tRNA ${ }^{\text {Phe }}$, all of which inhibited only at higher concentrations. Based on the amount of the Neurospora mt tRNA ${ }^{\mathrm{Tyx}}$ required for half-maximal inhibition and the measured $K_{\mathrm{d}}$ for the complex between the CYT-18 protein and the intron RNA, we calculated that the $K_{\mathrm{d}}$ for the binding of Neurospora mt tRNA ${ }^{\mathrm{Tyr}}$ is
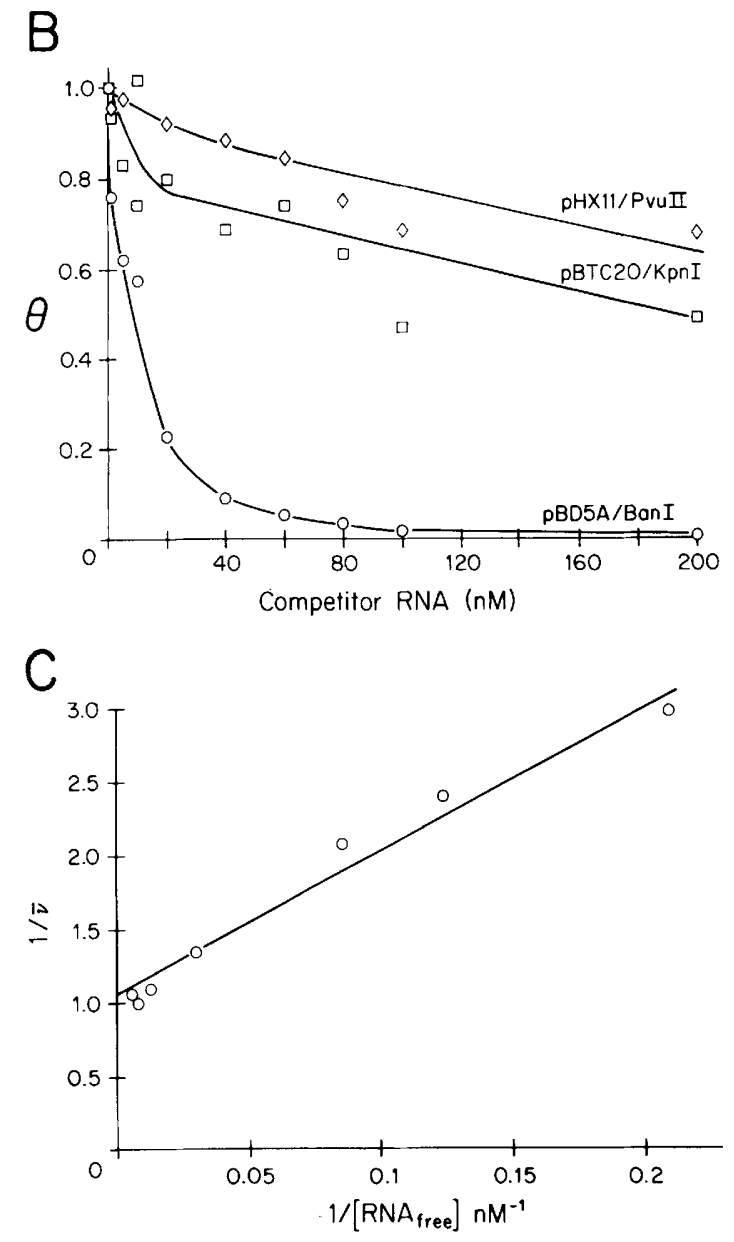
Table 2. Binding of the CYT-18 protein to different introns

\begin{tabular}{|c|c|c|c|}
\hline Intron & Plasmid & Group & $K_{\mathrm{d}}(\mathrm{nM})$ \\
\hline \multicolumn{4}{|l|}{ Nc. mt LSU } \\
\hline $\begin{array}{l}\text { Nc. mt LSU } \\
\text { (full length) }\end{array}$ & $\mathrm{pHX} 11 /$ Ban $I^{\mathrm{a}}$ & IAl & $10+2$ \\
\hline Sc. $\mathrm{mt} \mathrm{LSU}$ & $\mathrm{pBS} \omega / \mathrm{SalI} \mathrm{I}^{\mathrm{b}}$ & IAl & $11 \pm 2$ \\
\hline Pa. mt LSU-Il & $\mathrm{pRII} / E c o \mathrm{RI}^{\mathrm{c}}$ & IA 1 & $36 \pm 2$ \\
\hline $\mathrm{T} 4 t d$ & $\mathrm{pBStd} / E \operatorname{coRV} \mathrm{V}^{\mathrm{d}}$ & IA2 & $16 \pm 2$ \\
\hline $\mathrm{T} 4 \mathrm{nrdB}$ & pJSE17/HpaI ${ }^{\mathrm{e}}$ & IA 2 & $13 \pm 2$ \\
\hline $\mathrm{T} 4 \operatorname{sun} Y$ & pMAX $1 / X b a I^{f}$ & IA2 & $12 \pm 2$ \\
\hline Nc. ND1 & pND1/PvuII ${ }^{\mathrm{g}}$ & IB2 & $16 \pm 3$ \\
\hline Tt. LSU & pT7TT1A3/EcoRI ${ }^{\mathrm{h}}$ & $\mathrm{ICl}$ & $>188 *$ \\
\hline Nc. ND4L & pND4L/EcoRI ${ }^{\mathrm{g}}$ & $\mathrm{ICl}$ & $58 \pm 9$ \\
\hline Nc. $N D 3$ & $\mathrm{pND} 3 / X b a \mathrm{I}^{\mathrm{i}}$ & IC2 & $46 \pm 8$ \\
\hline Nc. $N D 4$ & pND4/PVuI ${ }^{\mathrm{g}}$ & IC2 & $51 \pm 1$ \\
\hline Nc. $c o b-\mathrm{Il}$ & pSP64-H2a/Xmni $\mathrm{I}^{\mathrm{i}}$ & ID & $38 \pm 8$ \\
\hline Sc. $c o b-\mathrm{Il}$ & $\mathrm{pSDHl} /$ Bam HI $^{\mathrm{k}}$ & II & $>188 *$ \\
\hline Sc. $\operatorname{cox} 1-15 \gamma$ & pID20/HindIII ${ }^{1}$ & II & $>188^{*}$ \\
\hline
\end{tabular}

The binding of the CYT- 18 protein to ${ }^{32}$ P-labeled RNAs containing different introns was measured by the nitrocellulose filter method. Group I introns are classified according to Michel and Westhof (1990). References: ${ }^{a}$ This paper. ${ }^{b}$ Provided by Dr. Peter Zassenhaus (St. Louis University, MO); the transcript was synthesized with T7 RNA polymerase and consists of the 483nucleotide 5 ' exon, the 1143-nucleotide intron, and the 61-nucleotide 3 ' exon. ' ${ }^{\prime}$ Heinen (1991). dBelfort et al. (1987). ${ }^{\mathrm{e}}$ Gott et al. (1986). ' Shub et al. (1987). G. Wallweber and A. Lambowitz (unpubl.). For pND1/PvuII, the transcript was synthesized with T3 RNA polymerase and consists of the 539-nucleotide 5 ' exon, the 1118-nucleotide intron, and the 738-nucleotide $3^{\prime}$ exon. For pND4/PvuI, the transcript was synthesized with T3 RNA polymerase and consists of the 708-nucleotide $5^{\prime}$ exon, the 1449nucleotide intron, and the 984-nucleotide 3 ' exon. For pND4L/ EcoRI, the transcript was synthesized with T3 RNA polymerase and consists of the 696-nucleotide 5' exon, the 1492-nucleotide

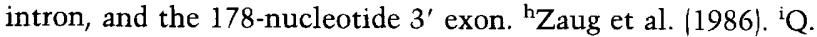
Guo and A. Lambowitz (unpubl.). The transcript was synthesized with T7 RNA polymerase and consists of the 130-nucleotide $5^{\prime}$ exon, the 1449-nucleotide intron, and the 285-nucleotide 3' exon. 'Garriga and Lambowitz (1984). ${ }^{\mathrm{k}} \mathrm{Dib}-\mathrm{Hajj}$ (1990). ${ }^{1}$ Jarrell et al. (1988). $(*)$ Binding was not saturated at the indicated concentration of the CYT-18 protein. Data are mean \pm S.D. for at least two independent experiments for each intron. (For abbreviations, see legend to Fig. 8.)

ity was assayed with different amounts of Neurospora mt tRNA ${ }^{\text {Tyr }}$ substrate and intron inhibitor. A HanesWoolf plot of the data gave a series of parallel lines, indicating that the intron RNA is a competitive inhibitor (Fig. 4). The calculated $K_{\mathrm{I}} \sim 39 \mathrm{nM}$, is in reasonable agreement with the $K_{\mathrm{d}}$ value for the intron at the $\mathrm{pH}$ of synthetase reaction medium $\left(K_{\mathrm{d}}=26 \mathrm{nM}\right.$ at $\left.\mathrm{pH} 8.8\right)$ and shows again that the intron binds more strongly than the tRNA $\left(K_{\mathrm{m}}=5.7 \mu \mathrm{M}\right.$ in this experiment). The finding that the inhibition is competitive provides evidence that the binding site for the intron overlaps that for the tRNA.

The CYT-18 protein binds to the group I intron catalytic core

To localize the CYT-18 protein-binding site in the intron
RNA, we tested derivatives of the 388-nucleotide $\mathrm{mt}$ large rRNA intron containing truncations or internal deletions for their ability to bind the CYT- 18 protein by the nitrocellulose filter-binding method. Binding curves for $5^{\prime}$ and $3^{\prime}$ truncations are shown in Figure 5 , and $K_{\mathrm{d}}$ values for the mutant introns are summarized in Figure 6.

From the $5^{\prime}$ end, introns having truncations that remove 97 nucleotides and extend up to the second nucleotide of $\mathrm{P} 3\left[5^{\prime}\right]$ retained essentially full binding activity
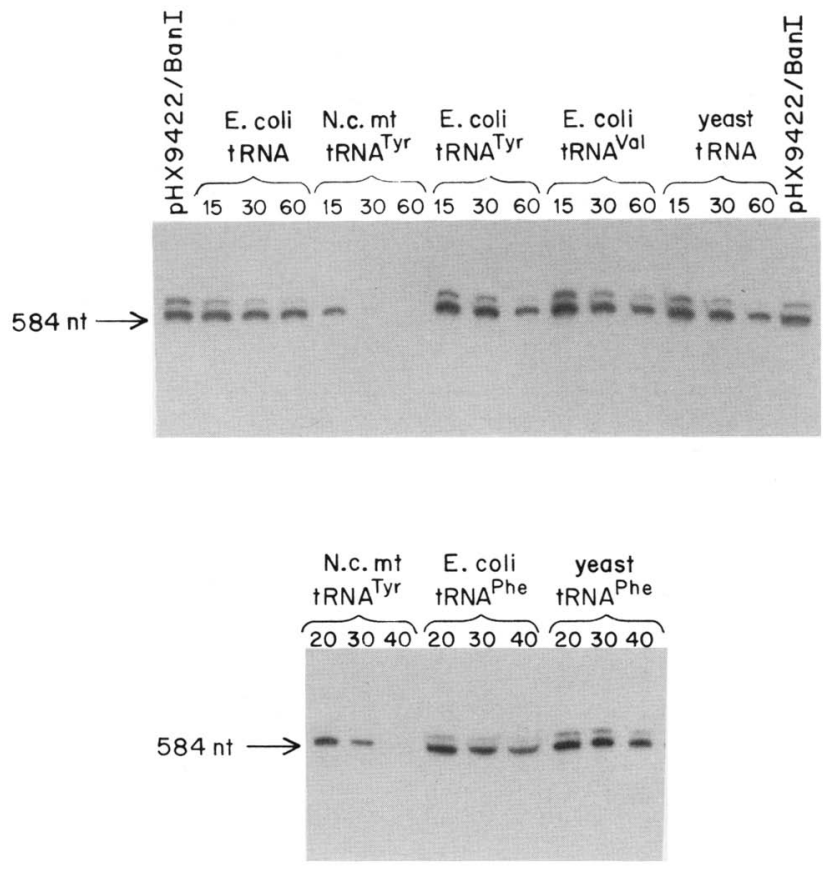

Figure 3. Splicing activity of the CYT-18 protein is inhibited by the Neurospora $\mathrm{mt}$ tRNA ${ }^{\mathrm{Tyr}}$. Different competitor RNAs in amounts $(\mu \mathrm{g})$ indicated were premixed with $0.5 \mu \mathrm{g}(0.11 \mu \mathrm{M})$ of pHX9422/BanI transcript, which contains a 583-nucleotide derivative of the Neurospora mt large rRNA intron. The molar concentrations of the tRNA species at $15 \mu \mathrm{g}$ ranged from 25 to $29 \mu \mathrm{M}$. Splicing was initiated by the addition of the CYT-18 protein purified from wild-type $74 A$ mitochondrial RNPs by heparin-Sepharose chromatography and assayed by the addition of $\left[\alpha^{-32} \mathrm{P}\right]$ GTP to the $5^{\prime}$ end of the excised intron. Neurospora crassa (N.c.) mt tRNA ${ }^{\text {Tyr }}$ was transcribed from plasmid pTYR/ $B s t N I$, and E. coli tRNA ${ }^{\text {Phe }}$ and yeast tRNA ${ }^{\text {Phe }}$ were transcribed from plasmids p67CF0/BstNI and p67YF0/BstNI, respectively. E. coli tRNA ${ }^{\text {Tyr }}$ was obtained from Subriden RNA (Rolling Bay, WA). E. coli tRNA ${ }^{\text {Val }}$ and mixed E. coli and yeast tRNAs were obtained from Sigma. The somewhat different concentrations of Neurospora mt tRNA ${ }^{\mathrm{Tyr}}$ required for inhibition in the top and bottom panels reflect the use of different CYT-18 protein preparations. The experiments shown in both panels were repeated at least once with essentially the same results. 
Table 3. The Neurospora mt large rRNA intron inhibits TyrRS activity of the CYT-18 protein

\begin{tabular}{|c|c|c|c|c|}
\hline Substrate & Competitor & $\begin{array}{l}\text { Amount } \\
(\mu \mathrm{g})\end{array}$ & $\mathrm{cpm}$ & $\begin{array}{l}\text { Activity } \\
(\%)\end{array}$ \\
\hline \multirow[t]{13}{*}{ E. coli $\mathrm{tRNA}{ }^{\mathrm{Tyr}}$} & none & 0 & 17,841 & 100 \\
\hline & \multirow[t]{3}{*}{ Nc mt large rRNA intron: pHX9422/BanI } & 5 & 50 & 0.3 \\
\hline & & 10 & 74 & 0.4 \\
\hline & & 20 & 132 & 0.7 \\
\hline & \multirow[t]{3}{*}{ Nc mt large rRNA intron: pBD5A/BanI } & 5 & 0 & 0 \\
\hline & & 10 & 6 & 0 \\
\hline & & 20 & 1,070 & 3 \\
\hline & \multirow[t]{3}{*}{ 5' exon: pHX11/PvuII } & 5 & 15,712 & 88 \\
\hline & & 10 & 14,992 & 84 \\
\hline & & 20 & 11,196 & 63 \\
\hline & \multirow[t]{3}{*}{ yeast total RNA } & 5 & 25,427 & 142 \\
\hline & & 10 & 25,357 & 142 \\
\hline & & 20 & 22,759 & 127 \\
\hline \multirow[t]{10}{*}{ Nc mt tRNA ${ }^{\text {Tyr }}$} & none & 0 & 16,561 & 100 \\
\hline & \multirow[t]{3}{*}{ Nc mt large rRNA intron: pHX9422/BanI } & 5 & 407 & 2.5 \\
\hline & & 10 & 381 & 2.3 \\
\hline & & 20 & 401 & 2.4 \\
\hline & \multirow[t]{3}{*}{ Nc mt large rRNA intron: pBD5A/BanI } & 5 & 479 & 2.9 \\
\hline & & 10 & 451 & 2.7 \\
\hline & & 20 & 494 & 3.0 \\
\hline & \multirow[t]{3}{*}{ 5' exon: $\mathrm{pHX} 11 / \mathrm{P}_{v u I I}$} & 5 & 16,566 & 100 \\
\hline & & 10 & 15,869 & 96 \\
\hline & & 20 & 13,632 & 82 \\
\hline
\end{tabular}

tRNA $^{\text {Tyr }}$ substrate $(1 \mu \mathrm{g})$ was premixed with competitor RNA at the concentrations indicated, and TyrRS reactions were initiated by adding CYT- 18 protein preparation $(28 \mu \mathrm{g}$ of micrococcal nuclease-digested mitochondrial RNP preparation from $N$. crassa wild-type $74 A$ ). The experiment was repeated three times using different CYT-18 protein preparations with similar results. (Nc) Neurospora crassa.

for the CYT-18 protein ( 1 and 2, L95 and L97; $K_{\mathrm{d}}=7$ and $6 \mathrm{nM}$, respectively|, indicating that the $5^{\prime}$ splice site, $\mathrm{P} 1$, $\mathrm{P} 2$, and part of $\mathrm{P} 3$ are not required for binding. However, truncations that extend as few as 10 nucleotides farther to the second nucleotide of $\mathrm{P} 4\left[5^{\prime}\right]$ resulted in sharply decreased binding ( 3 and 4, L107 and L129). This sharp decrease was confirmed by additional experiments testing the ability of the mutant introns to compete with the wild-type intron for splicing activity of the CYT-18 protein (not shown).

From the $3^{\prime}$ end, the largest truncation that retained full binding activity was $\mathrm{R} 367$, which removes 22 nucleotides from the $3^{\prime}$ end of the intron $\left(5, K_{d}=5 \mathrm{~nm}\right)$. More extensive $3^{\prime}$ truncations that delete sequences between P9 and P6 resulted in a progressive increase in $K_{\mathrm{d}}$ up to $13 \mathrm{nM}$ for a truncation in $\mathrm{J6/7}(9, \mathrm{R} 243)$. Although this corresponds to a relatively small decrease in binding affinity, it is easily detectable in the binding assays and appears to be significant. The same effect was observed in two independent repeats of the experiment in which transcripts were assayed in parallel and was confirmed by additional experiments in which the $3^{\prime}$ truncations were tested for ability to compete binding of the wildtype intron (pBD5A/BanI; Fig. 5C) and by experiments testing the ability of mutant introns to compete with wild-type intron for splicing activity (not shown). Truncations that extend beyond $\mathrm{J} 6 / 7$ into $\mathrm{P} 6$ resulted in strongly decreased binding, as judged by loss of ability to

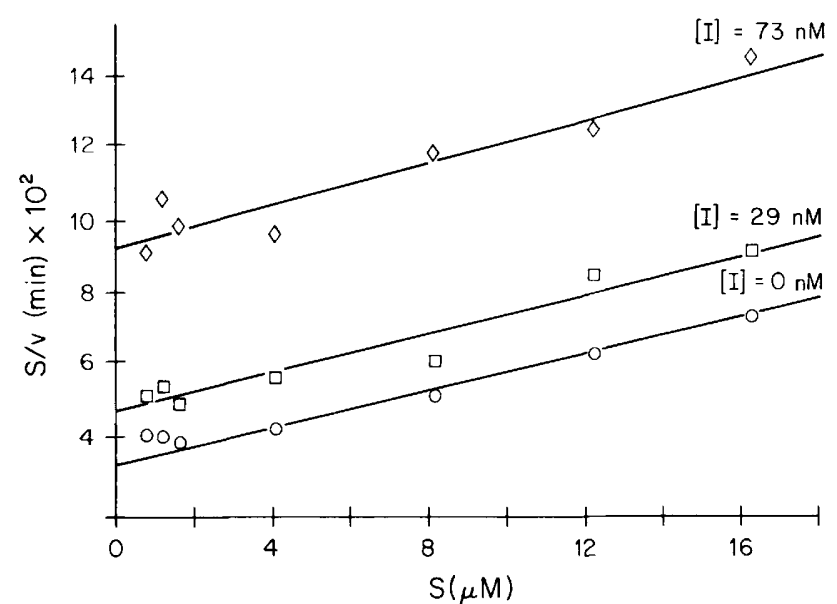

Figure 4. Competitive inhibition of TyrRS activity of the CYT-18 protein by the Neurospora mt large rRNA intron. Different amounts of Neurospora mt tRNA ${ }^{\text {Tyr }}$ substrate were premixed with intron RNA (pBD5A/BanI) at the concentrations indicated. TyrRS reactions were initiated by the addition of the CYT-18 protein preparation $(28 \mu \mathrm{g}$ of micrococcal nuclease-digested mitochondrial RNPs from $N$. crassa wild-type $74 A$ ). The substrate concentration $\left[\mathrm{S}(\mu \mathrm{M})\right.$ Neurospora $\mathrm{mt}$ tRNA $\left.{ }^{\mathrm{Tyr}}\right] \mathrm{di}-$ vided by the rate of product formation $(\mathrm{v}, \mu \mathrm{M} / \mathrm{min})$ is plotted as a function of the substrate concentration [S $(\mu \mathrm{M})$ ] [Dixon and Webb 1979). (I) The concentration of the inhibitor intron RNA (pBD5A/BanI). The data are averages for duplicate samples. 
A
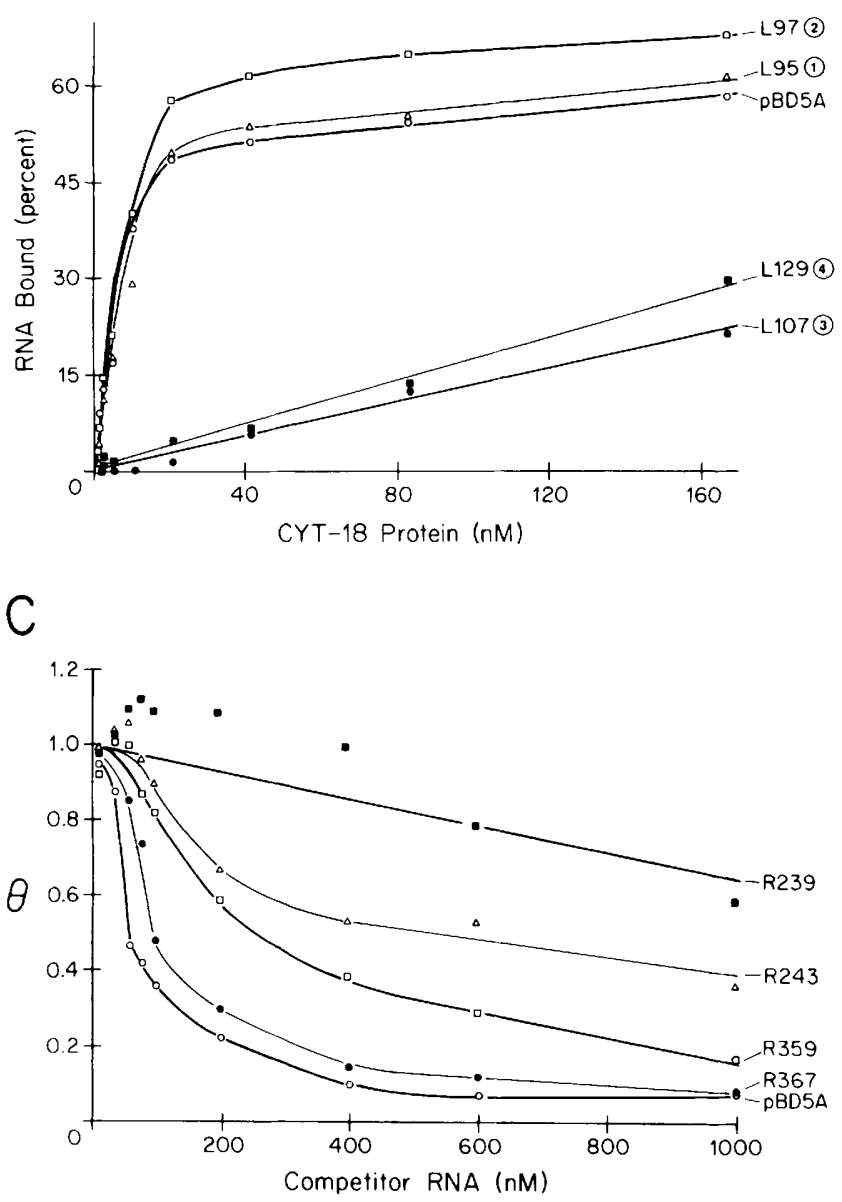

compete with the wild-type intron for splicing activity (not shown) and by nitrocellulose filter-binding assays (e.g., R175, 10 in Fig. 5B; or R239, which deletes only 1 nucleotide into P6, in Fig. 5C).

In addition to the regions identified by $5^{\prime}$ and $3^{\prime}$ truncation, we found that several internal regions of the intron could be removed without affecting binding (Fig. 6B). These include P6b and part of L6a $\left(14, K_{\mathrm{d}}=6 \mathrm{nM}\right)$, P7. 1 and P7.2 $\left(15, K_{\mathrm{d}}=6 \mathrm{nM}\right)$ and part of P8 $\left(16, K_{\mathrm{d}}=7\right.$ nM). Deletion of P5 or P6a resulted in moderate decreases in binding $\left(12, K_{\mathrm{d}}=43 \mathrm{nM} ; 13, K_{\mathrm{d}}=52 \mathrm{nM}\right)$, whereas deletion of P4 and P5 near the base of P4 resulted in strongly decreased binding $(11$; Fig. $6 \mathrm{~B})$.

\section{Construction of small RNAs containing the CYT-18 protein-binding site}

Together, the above results indicate that the intron contains a high-affinity binding site for the CYT-18 protein in the P4-P5-P6-P6a region, and there may be an additional contribution from the P7-P9 region. To confirm the location of the high-affinity binding site, we synthesized an RNA that contains a 75-nucleotide region of the intron encompassing $\mathrm{P} 4\left[5^{\prime}\right]$ to $\mathrm{P} 6\left[3^{\prime}\right]$, excluding se-

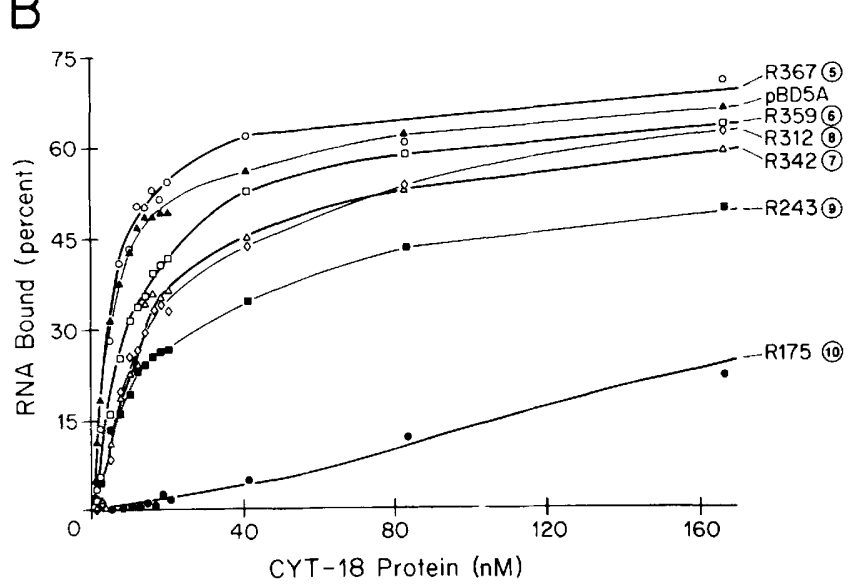

Figure 5. Nitrocellulose filter assay of binding of the CYT-18 protein to derivatives of the Neurospora mt large rRNA intron. $(A, B)$ Binding of the CYT- 18 protein to derivatives of the mt large rRNA intron having $5^{\prime}$ - or $3^{\prime}$-truncations. The percentage of ${ }^{32} \mathrm{P}$-labeled RNA retained on the filter is plotted as a function of concentration of the CYT-18 protein dimer (nM). (C) Binding of the Neurospora $\mathrm{mt}$ large rRNA intron competed by a series of RNAs having $3^{\prime}$ truncations of intron sequences. ${ }^{32} \mathrm{P}$-Labeled RNA containing the intron (pBD5A/BanI) was mixed with different concentrations of unlabeled competitor RNAs, as indicated. The CYT- 18 protein was added, and nitrocellulose filter-binding assays were carried out under standard conditions. The amount of RNA bound in the presence of the competitor divided by the amount bound in the absence of the competitor $(\theta)$ is plotted as the function of the competitor RNA concentration. All experiments were repeated at least once with essentially the same results. Circled numbers identify RNAs depicted schematically in Fig. 6.

quences distal to L6a (RNA 1; Fig. 7). The CYT-18 protein bound this RNA with a $K_{\mathrm{d}}$ of $13 \mathrm{nM}$, in good agreement with the results expected from $5^{\prime}$ and $3^{\prime}$ truncations. Starting with this small RNA, we tested derivatives that add additional 3 ' sequences. Addition of P7[5'] had no effect on $K_{d}$ (RNA 2; Fig. 7), whereas addition of the $3^{\prime}$ end of the intron, including $\mathrm{P7}$ and $\mathrm{P} 9$, gave a $K_{\mathrm{d}}$ of $6 \mathrm{nM}$, similar to that for the full-length intron (RNA 3; Fig. 7). Because the experiments in Figure 6 show that sequences distal to $\mathrm{P} 9$ have no effect on binding, we infer that the tighter binding of the latter RNA is the result of sequences in P7-P9. In control experiments, addition of similar-length sequences that did not restore P7 and P9 either had no effect on binding or resulted in an increased $K_{\mathrm{d}}$, presumably owing to nonspecific interference with the binding of CYT-18 (not shown).

The contribution of P7-P9 could indicate that P7-P9 is required for correct folding of P4-P5-P6-P6a or that the intron contains at least two binding sites for CYT-18, one in P4-P5-P6-P6a and the other in P7-P9. Based on the measured $K_{\mathrm{d}}$ values, we calculate that binding of CYT18 to P4-P5-P6-P6a contributes $-10.7 \mathrm{kcal} / \mathrm{mole}$ to $\Delta \mathrm{G}^{\circ}$, whereas its potential binding to $\mathrm{P} 7-\mathrm{P} 9$ would contribute only an additional $-0.5 \mathrm{kcal} / \mathrm{mole}$. By itself, $\mathrm{P} 7-\mathrm{P} 9$ is 


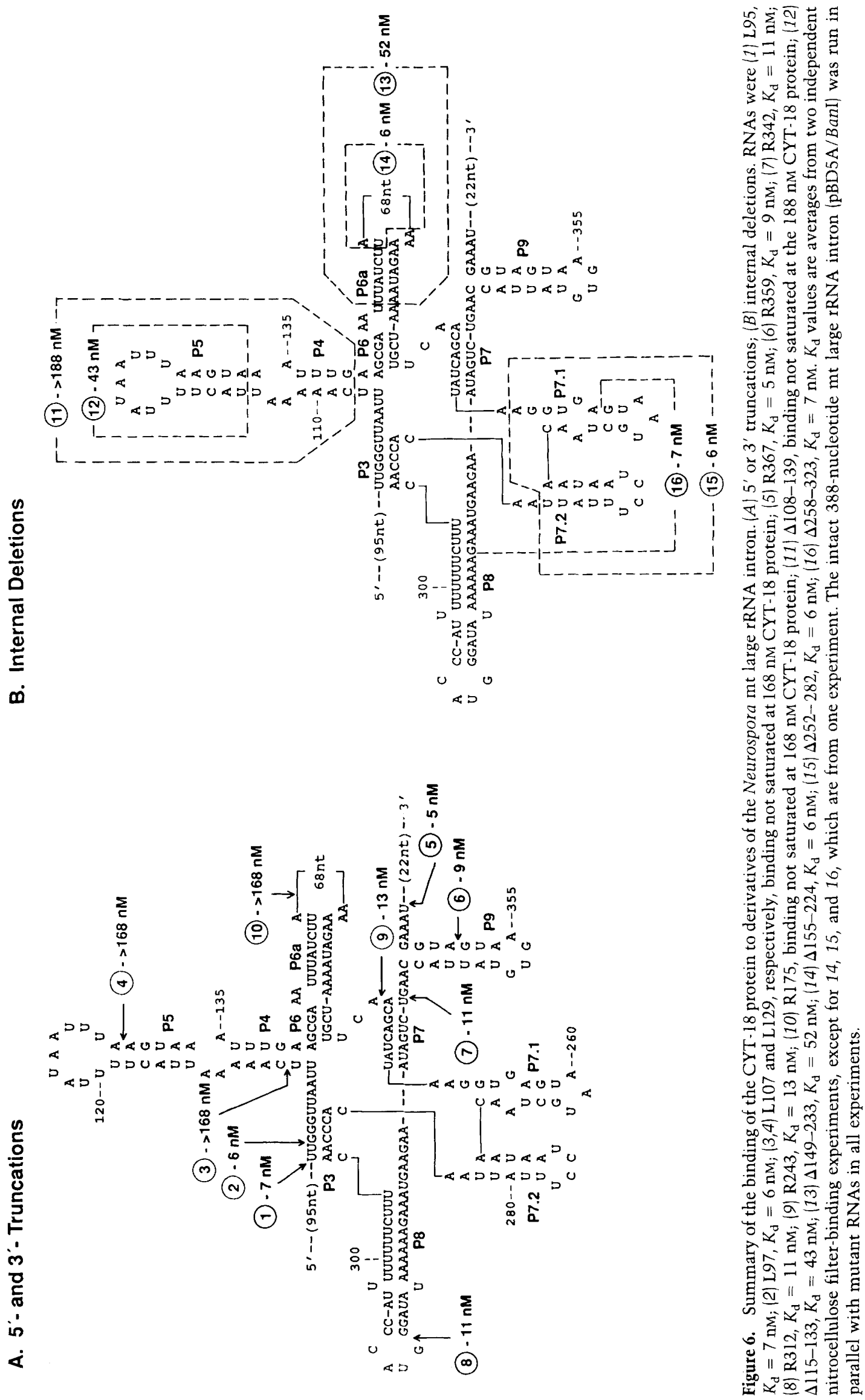




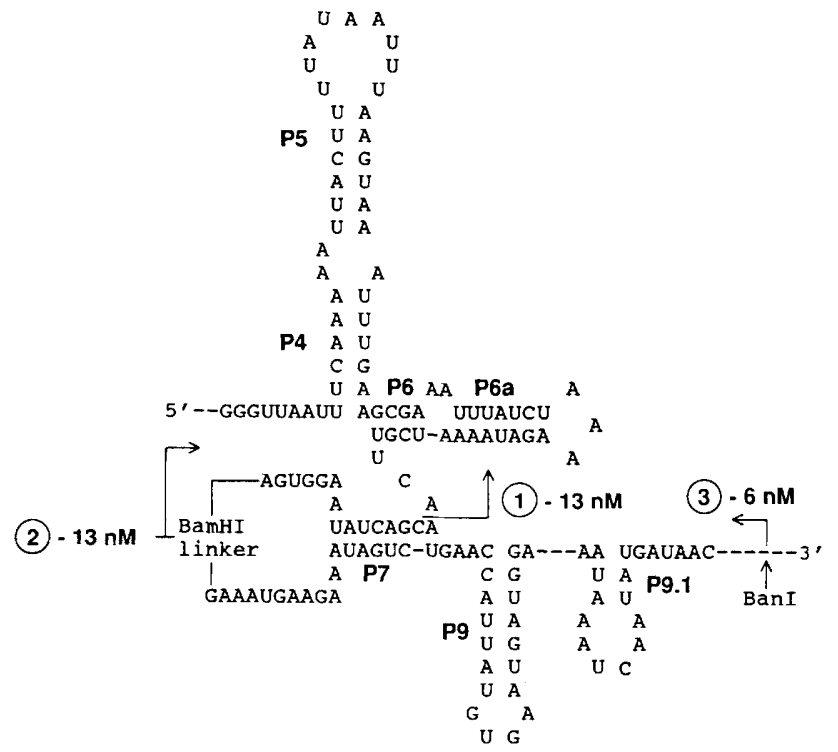

Figure 7. Binding of the CYT-18 protein to small RNAs containing different regions of the Neurospora mt large rRNA intron catalytic core. (1) pI75/BamHI, RNA containing 75 nucleotides of the intron encompassing J3/4 to J6/7 with sequences distal to P6a deleted. (2) pR258/BamHI, RNA containing the same 75-nucleotide intron sequences as RNA 1 plus an additional 15 nucleotide adding P7[5']. (3) p $\Delta 258-323 /$ BanI, RNA containing the same intron sequences as RNA 2 plus an additional segment restoring P7 and P9 and extending into the 3' exon. In addition to intron sequences, all three RNAs have the vector sequence between the T3 promoter and the HindIII site (GGGAACAAAAGCTTGG) attached to the 5' end of the RNA, and RNAs 1 and 2 have part of a BamHI linker (CCGGATC) attached to the $3^{\prime}$ end. RNA 3 has a BamHI linker sequence (CCGGATCCGG) between P7[5'] and P7[3']. $K_{d}$ values for 1 and 3 are averages from two separate experiments, whereas the $K_{\mathrm{d}}$ value for 2 is from one experiment.

expected to have a relatively high $K_{\mathrm{d}}$, above the range readily measured by nitrocellulose filter-binding assay. We attempted to measure the binding of the P7-P9 region to CYT-18 by inhibition of TyrRS activity, but in this experiment an RNA beginning in $\mathrm{P} 6 \mathrm{~b}$ (NheI site) and extending through the $3^{\prime}$ end of the intron had a $K_{\mathrm{I}}$ of 2.4 $\mu \mathrm{M}$, only slightly better than inhibition by nonspecific RNAs ( $K_{\mathrm{I}}{ }^{\prime} \mathrm{s}=4-12 \mu \mathrm{M}$; not shown).

\section{Comparison of group I introns that bind and are spliced by the CYT-18 protein}

In general, different group I introns have minimal sequence homology $(<10 \%)$, but all share conserved secondary and tertiary structures that are required for catalytic activity (Cech 1990; Michel and Westhof 1990; Heuer et al. 1991). Figure 8 is a schematic comparing six different introns (Nc LSU, Nc ND1, Sc LSU, Pa LSU1, T4 $t d$, and Tt LSU with P5abc deleted) that both bind and can be spliced in vitro by the CYT-18 protein. The region containing the high-affinity binding site, P4-P5-P6-P6a, has little sequence similarity in these introns, except for the $A$ residues in $J 3 / 4, L 4 / 5$, and $L 6 / 6 a$, which are conserved in most group I introns. Outside of this region, the only extensive conserved sequence is $\mathrm{P} 7$, which is highly conserved in all group I introns.

\section{Discussion}

We show here that the CYT-18 protein, the Neurospora $\mathrm{mt}$ TyrRS, binds strongly to a number of different group I introns, and we localized the CYT-18 protein-binding site in the Neurospora mt large rRNA intron to a highly conserved region of the group I intron catalytic core. Previous work showed that the CYT-18 protein functions in splicing a number of different group I introns in Neurospora mitochondria (Collins and Lambowitz 1985) and could also promote splicing of mutants of the phage T4 $t d$ or yeast $\omega^{+}$introns that have structural defects in different regions of the catalytic core (e.g., P4, P5, P6, J6/7, P7, P8, and P9; Mohr et al. 1992). Together, these results indicate that the CYT-18 protein functions in splicing by binding to highly conserved structural features of the group I intron core and stabilizing the core in a conformation required for catalytic activity.

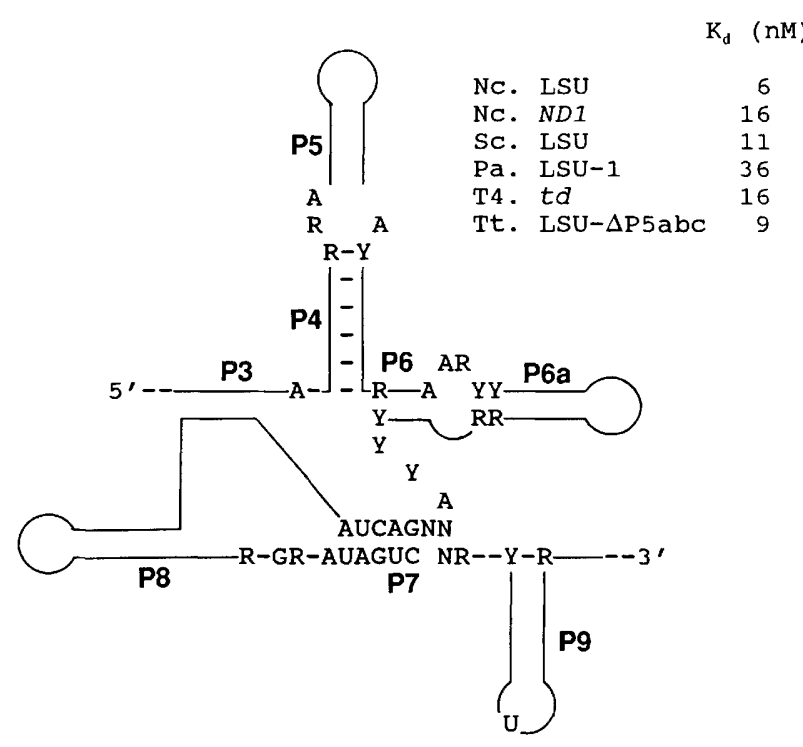

Figure 8. Comparison of the different introns that bind and are spliced by the CYT-18 protein. The introns compared are the $N$. crassa $(\mathrm{Nc}) \mathrm{mt}$ large rRNA intron, the Saccharomyces cerevisiae (Sc) mt large rRNA intron [(Dujon 1980); in vitro splicing (G. Mohr, G. Wallweber, and A. Lambowitz, unpubl.)], the Podospora anserina (Pa) $\mathrm{mt}$ large rRNA intron 1 (Heinen 1991), the bacteriophage T4 $t d$ intron (Chu et al. 1984; Mohr et al. 1992), the $N$. crassa ND1 intron [(Burger and Werner 1985); in vitro splicing (G. Wallweber and A. Lambowitz, unpubl.)], and the Tetrahymena $(\mathrm{Tt})$ large rRNA intron derivative lacking P5a,b,c [(Joyce et al. 1989); in vitro splicing (Q. Guo and A. Lambowitz, unpub1.)]. Nucleotides conserved in all introns are indicated in the structure. $(R, Y)$ Conserved purine or pyrimidine, respectively. (N) Any nucleotide found at a position. For some introns, the published structures of the P6/P6a junction region have been modified to maximize similarity. 
The findings that the Neurospora mt large rRNA intron is a competitive inhibitor of aminoacylation and that the Neurospora mt tRNA ${ }^{\text {Tyr }}$ inhibits splicing indicate that the intron-binding site in the CYT-18 protein overlaps the binding site for the tRNA. This conclusion is consistent with findings that regions of the CYT-18 protein required for splicing, including part of the idiosyncratic amino-terminal domain, may also be involved in binding tRNA ${ }^{\mathrm{Tyr}}$ (see introductory section) and that small linker insertions in the putative carboxy-terminal tRNA-binding domain have parallel effects on splicing and synthetase activity (Kittle et al. 1991; G. Mohr, A. Cherniack, G. Guo, J. Gianelos, and A.M. Lambowitz, unpubl.).

The binding of CYT-18 protein to the intron RNA $\left(K_{\mathrm{d}}=6 \mathrm{nM}\right)$ appears to be substantially stronger than is its binding to tRNA ${ }^{\text {Tyr }}$ (estimated $K_{\mathrm{d}}=2-7 \mu \mathrm{M}$; see Results). A caveat here is that for experimental reasons the tRNAs used for assays were either $E$. coli $\mathrm{tRNA}^{\mathrm{Tyr}}$ or an in vitro transcript of Neurospora crassa mt tRNA ${ }^{\mathrm{Tyr}}$, which lacks modified nucleotides and, for that reason, may not be optimally recognized by the synthetase. Nevertheless, the observed $K_{\mathrm{d}}$ in the micromolar range is similar to that for other tRNA/synthetase complexes, which generally have relatively high $K_{\mathrm{d}}$ values to facilitate rapid turnover for protein synthesis (Schimmel 1987, 1989). The tighter binding of the intron indicates either that additional interactions are involved and/or that binding of the intron requires less distortion of RNA structure than does binding of the tRNA /cf. Rould et al. 1989|. Because the difference in $K_{d}$ values for the intron and tRNA corresponds to a relatively small difference in $\Delta \mathrm{G}^{\circ}(-11.2 \mathrm{kcal} / \mathrm{mole}$ for the intron compared with $-8.5 \mathrm{kcal} / \mathrm{mole}$ for the tRNA), a relatively small number of additional interactions may be involved.

Although different group I introns have only minimal sequence homology and can be divided into subclasses based on ancillary structures, all have similar secondary and tertiary structures that include a highly conserved core region required for catalytic activity (Cech 1990; Michel and Westhof 1990; Heuer et al. 1991). The CYT18 protein binds directly to this catalytic core and presumably recognizes structural features that are conserved in different group I introns. Because most group I introns have not coevolved with the CYT-18 protein and are not normally dependent on it for splicing, we infer that these structural features are conserved for some other reason, presumably because they are required for catalytic activity.

Our results show that the CYT-18 protein binds strongly to the P4-P5-P6-P6a region of the intron core. By itself, an RNA containing 75 nucleotides from this region binds the CYT-18 protein with a $K_{\mathrm{d}}$ of $13 \mathrm{nM} /-10.7$ $\mathrm{kcal} / \mathrm{mole})$. Intron mutants lacking P5 and P6a still bind CYT-18 relatively strongly $\left(K_{\mathrm{d}}=43\right.$ and $52 \mathrm{nM}$, respectively; Fig. 6B), suggesting that key features are probably in P4-P6. Comparison of six different group I introns that both bind and can be spliced in vitro by the CYT-18 protein showed relatively little sequence similarity in P4-P6, raising the possibility that the protein recognizes conserved secondary and/or tertiary structure features of this region.

The previous finding that regions required for splicing are distributed throughout the CYT-18 protein and include both amino- and carboxy-terminal domains suggests that the protein contacts the intron at more than one site (see introductory section). In addition to P4-P5$\mathrm{P} 6-\mathrm{P} 6 \mathrm{a}$, we find that the $\mathrm{P} 7-\mathrm{P} 9$ region is required for maximal binding of the CYT-18 protein, either because it is necessary for optimal folding of P4-P5-P6-P6a or because it contains a second binding site for the protein. The possibility that CYT-18 binds to these two regions is consistent with findings with the phage $t d$ intron that CYT-18 exerts its effect over a wide area of the catalytic core and can efficiently suppress mutations in P7 and P9, as well as P4 and P6 (Mohr et al. 1992). If there is a second binding site in the $\mathrm{P} 7 / \mathrm{P} 9$ region, the higher $K_{\mathrm{d}}$ for this site could reflect either weaker interaction with the protein or the coupling of binding to an energetically unfavorable conformational change.

Figure 9A shows a three-dimensional model for the Tetrahymena rRNA intron catalytic core interacting with P1 and P10 (Michel and Westhof 1990). Although the Tetrahymena intron belongs to a different structural class than the Neurospora mt large rRNA intron, it nevertheless binds CYT-18 strongly $\left(K_{\mathrm{d}}=9 \mathrm{nM}\right.$; Q. Guo, L. Zhao, and A.M. Lambowitz, unpubl.) and must therefore contain all structural features essential for tight binding. According to the structural model, the catalytic core of the intron consists of two extended helices, one formed by the stacking of P6-P4-P5 and the other, P8-P3-P7, with the active site formed by a cleft between the two helices. The high-affinity binding site for CYT-18 is located on one helix, and the possible low affinity site is on the other helix. If there are binding sites on both helices, a major function of the CYT-18 protein may be to stabilize the two helices in the correct relative orientation to form the active site. This possibility is consistent with the finding that the CYT-18 protein suppresses mutations of the $\mathrm{J} 6 / 7$ region in the phage $t d$ or yeast $\omega^{+}$introns, which is believed to be involved in tertiary contacts that play a key role in establishing the correct orientation of the two major helices (Michel and Westhof 1990; Mohr et al. 1992). Furthermore, it may also explain why the CYT-18 protein can suppress mutations in many different regions of the intron core, all of which potentially interfere with establishing the correct orientation of the two helices.

The findings that the CYT-18 protein is a synthetase and uses the same or overlapping regions to bind both the intron and tRNA have three explanations, which are not mutually exclusive: (1) The protein may bind to different RNA motifs in the intron core and the tRNA; (2) the protein may bind to small sequences or structural motifs that are present in both the intron core and the tRNA; or (3) the protein may recognize similar overall three-dimensional structures of the intron core and tRNA.

Figure 9, B and C, compares the model for the part of the group I intron core involved in binding CYT-18 pro- 


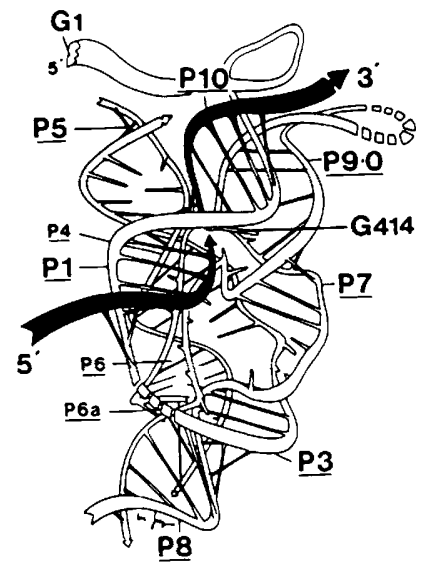

A

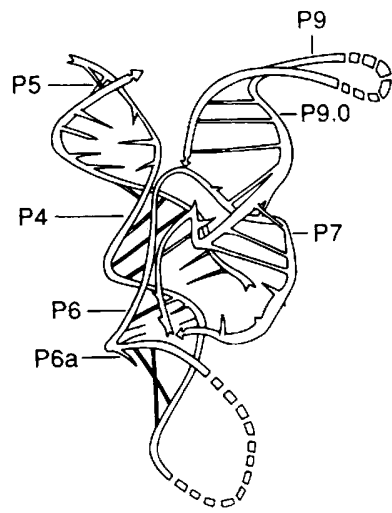

B

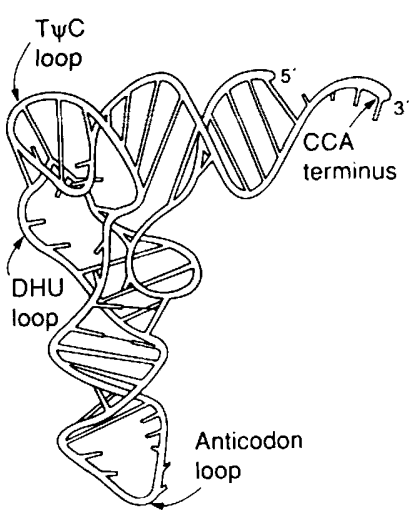

C

Figure 9. Comparison of the three-dimensional structures of group I introns and tRNA. $|A|$ Three-dimensional model of the Tetrahymena large rRNA intron from Michel and Westhof (1990). (G1, G414) The 5' and 3' nucleotides of the intron. (B) Same as $A$, except that regions not required for binding the CYT-18 protein have been deleted and the segment corresponding to P6a has been closed by a loop. (C). Three-dimensional structure of yeast tRNA ${ }^{\text {Phe }}$ adapted from Freifelder (1987).

tein with the three-dimensional structure of yeast tRNA ${ }^{\text {Phe }}$. Michel and Westhof (1990) noted that the stacked helix formed by P6 and P4 is structurally analogous to the tRNA helix formed by the stacking of the anticodon and $\mathrm{D}$-arms in being stabilized by base triples with both the incoming and outgoing single-stranded regions (J3/4 and $J 6 / 7$, in the case of the intron). The potential correspondence between the P4/P6 helix and the $\mathrm{D}$-arm/anticodon arm helix is supported by the finding that the carboxy-terminal domain of the protein, which in bacterial TyrRSs is believed to interact with the anticodon arm of tRNA ${ }^{\text {Tyr }}$ (Bedouelle 1990), is required for high-affinity binding of the intron and may therefore interact with the P4/P6 region (G. Mohr, A. Cherniack, G. Guo, J. Gianelos, and A.M. Lambowitz, unpubl.).

Figure 10 compares the sequences of the Neurospora $\mathrm{mt} \mathrm{tRNA}^{\mathrm{Tyr}}$ and the Neurospora $\mathrm{mt}$ large rRNA intron. For the purpose of comparison, the intron is drawn unconventionally in the form of a cloverleaf, using the potential correspondence between the D-arm/anticodon arm and the P4/P6 region of the intron for orientation. The degree of sequence similarity is surprisingly high (circled nucleotides), but only a subset of the matching nucleotides correspond to those conserved in other group I introns shown to bind CYT-18 functionally /shaded nucleotides). Of the features that are conserved, the most striking is the similarity in both sequence and secondary structure between the P7 stem and the variable arm of the tRNA. In addition, P9 has a length of $7 \mathrm{bp}$, the same as that of an acceptor stem in five of the six introns to which CYT-18 binds functionally (Fig. 8), the exception being the Tetrahymena intron where P9 consists of $5 \mathrm{bp}$ with a bulged nucleotide and there is one extra nucleotide in L9. The relatively high degree of sequence similarities between the Neurospora $\mathrm{mt}$ large rRNA and $\mathrm{mt}$ tRNA ${ }^{\mathrm{Tyr}}$ may reflect coevolution with the CYT-18 pro- tein and could contribute to the somewhat tighter binding of the Neurospora mt large rRNA intron relative to other group I introns (Table 2).

The potential correspondence between P7 and the variable arm is intriguing, because the Neurospora $\mathrm{mt}$ tRNA $^{\text {Tyr }}$ belongs to a subclass of tRNAs (type II) characterized by long variable arms (Rich and RajBhandary 1976). The long variable arm has been implicated in the recognition of E. coli tRNA ${ }^{\text {Tyr }}$ (Himeno et al. 1990) and is an idiosyncratic feature that could interact with the idiosyncratic amino-terminal domain of the CYT-18 protein and contribute to the Neurospora $\mathrm{mt} \mathrm{tRNA}^{\mathrm{Tyr}}$ being a better inhibitor of splicing than is E. coli tRNA $^{\text {Tyr }}$. In the case of yeast tRNA ${ }^{\text {Ser }}$, which also has a long variable arm, footprinting experiments have shown that SerRS binds to both the variable arm and the base of the anticodon stem (Dock-Bregeon et al. 1990). If the situation is similar for the Neurospora mt TyrRS, a key structure involved in recognition may be the cognate of the variable arm, P7, hinged off the cognate of the anticodon arm, P4/P6 (cf. Dock-Bregeon et al. 1989, 1990).

The finding that splicing activity of the Neurospora $m t$ TyrRS requires an idiosyncratic amino-terminal domain not found in bacterial or yeast $m t$ TyrRSs suggests that the Neurospora mt TyrRS may have adapted to function in splicing relatively recently in evolution, after the divergence of Neurospora and yeast (Cherniack et al. 1990; Kämper et al. 1992). However, the present results raise the possibility that the TyrRS may have been predisposed to function in splicing by virtue of its ability to recognize conserved structural features of group I introns that resemble those in tRNAs. The possible structural similarities between group I introns and tRNAs could reflect convergent evolution leading to the presence of similar RNA sequence or structural motifs. The alternate possibility is that group I introns and tRNAs are 
Neurospora mt tRNA ${ }^{\text {tyr }}$

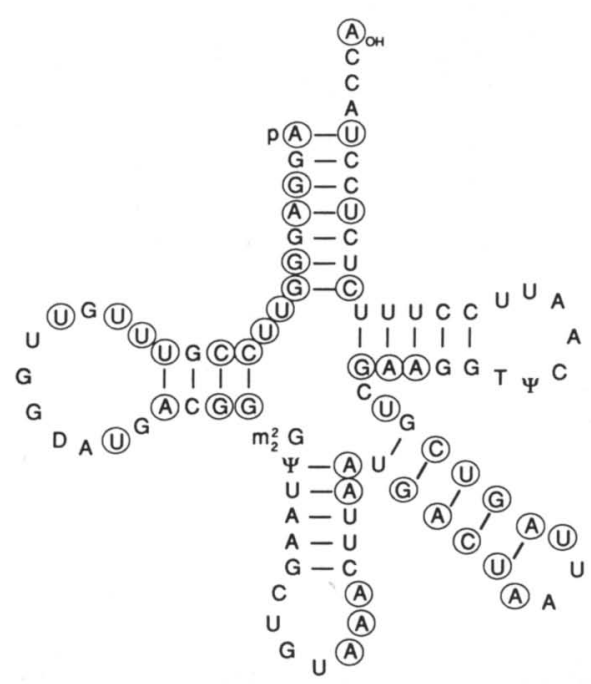

Neurospora mt LSU Intron

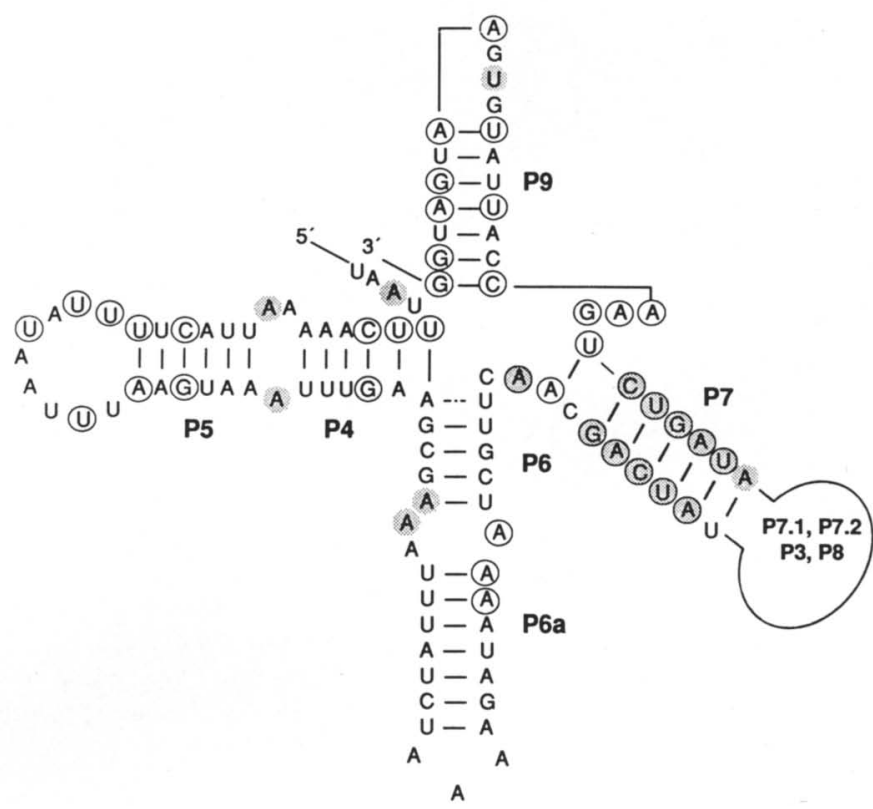

Figure 10. Comparison of the Neurospora $\mathrm{mt} t \mathrm{RNA} \mathrm{T}^{\mathrm{Tyr}}$ and the Neurospora $\mathrm{mt}$ large rRNA intron core. The structure of Neurospora mt tRNA ${ }^{\text {Tyr }}$ is from Heckman et al. (1979). The intron structure is drawn as a cloverleaf to facilitate comparison to the tRNA ${ }^{\mathrm{Ty}}$. Circled nucleotides are identical in the two structures. Shaded nucleotides are those conserved in the six group I introns that bind and are spliced by CYT-18 (see Fig. 8).

evolutionarily related. In principle, either RNA species could have evolved into the other. However, if we assume that group I introns are ancient, we can speculate that catalytically active RNAs, which were the ancestors of group I introns, also gave rise to tRNAs.

The possibility that group I RNAs evolved into tRNAs is consistent with the hypothesis that life began in an "RNA world," in which case all the machinery for protein synthesis, including tRNAs, would have had to evolve from catalytic RNAs. The possible involvement of catalytic RNAs in the evolution of protein synthesis was suggested early on (for review, see Darnell and Doolittle 1986) and has been reinforced by recent findings that the Tetrahymena ribozyme binds arginine (Yarus 1988) and that antibiotics that interact with the decoding region of $E$. coli $16 \mathrm{~S}$ rRNA specifically inhibit splicing of group I introns (von Ahsen et al. 1991). Weiner and Maizels (1987) proposed that tRNAs originated as "genomic tags" at the 3' ends of self-replicating, catalytically active RNAs and that such RNAs gave rise to both tRNAs and synthetases, which functioned in their own aminoacylation by RNA catalysis. Recently, Piccirilli et al. (1992) provided evidence for the feasibility of such a reaction by demonstrating that the Tetrahymena ribozyme could catalyze the reverse of an aminoacylation reaction, hydrolysis of an aminoacyl-ester bond attached to an oligonucleotide ending in CCA. Although present-day group I introns do not contain a CCA terminus, the Mauriceville plasmid, an autonomous element, which may be related to group I introns, has a CCA ter- minus and a 3'-terminal tRNA-like structure that may be a genomic tag for a reverse transcriptase encoded by the element (Kuiper and Lambowitz 1988). The objective now will be to solve the structure of the intron and its complex with the TyrRS to determine the extent of the structural similarities.

\section{Materials and methods}

Strains of Neurospora and growth conditions

The $N$. crassa wild-type 74-OR23-1A (designated 74A) was used in this study. Procedures for maintaining the strain, preparing conidia, and growing cells in liquid culture were as described (Davis and de Serres 1970; Lambowitz et al. 1979).

\section{Recombinant plasmids and construction of mutant introns}

Constructs containing the Neurospora mt large rRNA intron and its derivatives are summarized in Table 1. Plasmids pHX11, pHX9422, and pBD5A contain different forms of the Neurospo$r a \mathrm{mt}$ large rRNA intron cloned behind the phage $\mathrm{T} 3$ promoter in the $\mathrm{pBS}$ ( + ) vector (Guo et al. 1991). All three plasmids were linearized with BanI for in vitro transcription. The transcript from pHXll consists of an 844-nucleotide $5^{\prime}$ exon, the fulllength 2296-nucleotide intron, and a 50-nucleotide 3 ' exon. The transcripts from pHX9422 and pBD5A consist of a 65-nucleotide $5^{\prime}$ exon, 583- or 388-nucleotide derivatives of the intron, respectively, and a 50-nucleotide $3^{\prime}$ exon.

The mutant introns used in this study are related to pBD5A. To construct plasmids having $5^{\prime}$ truncations of intron sequences, plasmid pBD5, which is the same as pBD5A except for 
the polylinker region (Guo et al. 1991), was linearized at the SphI site in the P2 stem and digested with BAL31 (Slow) nuclease (International Biotechnologies, Inc., New Haven, CT) at $30^{\circ} \mathrm{C}$ for 10-60 min. The BAL31-digested plasmids were ligated with T4 DNA ligase in the presence of a HindIII linker (CCAAGCTTGG). Plasmids containing both the HindIII linker and appropriate inserts were isolated, and the deletion end points were sequenced (Sanger et al. 1977), by using the M13 reverse primer. HindIII-EcoRI fragments containing selected truncated introns were recloned between the HindIII and EcoRI sites of pBS( - ) to give plasmids pL95, pL97, pL107, and pL129, with the number in the plasmid name indicating the last nucleotide of the truncation. These plasmids were linearized with BanI and transcribed with phage T3 RNA polymerase (Stratagene, La Jolla, CA.).

Plasmids pBD5910, pBD591, and pBD5908, used to obtain RNAs having 3 ' truncations of intron sequences, were described (Guo et al. 1991) but have been renamed pR342, pR359, and pR367 to indicate the last nucleotide of the truncation. Plasmids with $3^{\prime}$ truncations upstream of $\mathrm{L} 8$ were constructed by BAL31 digestion of pBD5A linearized at the NcoI site at the end of P8. The BAL31-treated plasmids were ligated with T4 DNA ligase in the presence of a BamHI linker (CCGGATCCGG). Plasmids containing both the BamHI linker and inserts of appropriate size were isolated, and the deletion end points were sequenced (Sanger et al. 1977), by use of a primer complementary to the $3^{\prime}$ exon (CCGCGCACTCATTTTGTACAC). The resulting plasmids are named pR239, pR243, pR244, and pR258. These plasmids were linearized with $\mathrm{BamHI}$ and transcribed with T3 RNA polymerase. RNAs R175 and R312 were obtained from pBD5A linearized with NheI or NcoI, respectively.

Plasmid pBD541, which has a deletion of P4 and P5, was described (Guo et al. 1991) but has been renamed $\mathrm{p} \Delta 108-139$ to indicate the extent of the deletion. $\mathrm{p} \Delta 258-323$ was constructed by combining pR258 and pR244 at the BamHI sites in the linkers. Other plasmids having internal deletions of intron sequences were constructed from pBD5A by site-directed mutagenesis (Kunkel et al. 1987), by use of the following synthetic oligonucleotides: $\mathrm{p} \Delta 1$ 15-133: 5'-GATAAATTTCGCTTCAAATTATTTTTGAAATTAACCC-3'; p $\triangle 149-233$ : 5'-CCTTATAGTCGTTGAACGATTATTTCGCTTCAAATT-3'; p 1 155-224: $5^{\prime}$-GAACGATTTTATCTTNTAGATAAATTTCGCTTCAAATT-3'; p $\Delta 252-282:$ 5'-AAAAAGAAAGTTGGGTGTTTATAGTCGTTGAACG-3'.

Plasmids having internal deletions were linearized with BanI and transcribed with T3 RNA polymerase.

pRL96-242 and pRL98-242 were constructed by combining $5^{\prime}$ truncations pL95 and pL97, respectively, with $3^{\prime}$ truncation pR243 via the NheI site in P6b. Starting from these plasmids, pI75 and pI77 were constructed by deleting sequences distal to P6a by site-directed mutagenesis, by using the oligonucleotide for $\mathrm{p} \Delta 155-224$ (see above). These plasmids were linearized with BamHI and transcribed with T3 RNA polymerase.

Nonspecific transcripts used as controls were synthesized from $\mathrm{pHXll} /$ PvuII (Neurospora mt large rRNA gene, 171-nucleotide RNA containing sequences in the $5^{\prime}$ exon) or pBTC20/ KpnI (Neurospora cyt-20 gene, 869-nucleotide RNA corresponding to antisense strand; Kubelik et al. 1991), with T3 RNA polymerase.

In vitro synthesis of Neurospora mt $t R N A^{T y t}$ and other tRNAs

Plasmid pTYR, which was used to synthesize the Neurospora mt tRNA ${ }^{\mathrm{Tyr}}$, was constructed by polymerase chain reaction (PCR) cloning the Neurospora mt tRNA ${ }^{\mathrm{Tyx}}$ gene from plasmid
pHP2, which contains the PstI-5a fragment of wild-type $74 \mathrm{~A}$ mitochondrial DNA in pBR322 (Heckman and RajBhandary 1979). The primers for PCR cloning were $5^{\prime}$-AGCTAGCAATTAACCCTCACTAAA(A/G)GGAGGGTTCCGTTTGTTGG$3^{\prime}$ and 5'-CGGTACCTGGTAGGAGAGAAAGGAA-3'. The 5' primer contains a terminal NheI site for cloning and introduces a phage T3 promoter at the $5^{\prime}$ end of the tRNA ${ }^{\text {Tyr }}$ gene. The $3^{\prime}$ primer contains a BstNI site, which is used to linearize the plasmid for synthesis of an RNA ending in CCA, and a terminal KpnI site for cloning. After PCR amplification, the 121-nucleotide PCR product was digested with NheI and KpnI and inserted into the XbaI-KpnI site of pUC19.

To synthesize the Neurospora mt tRNA ${ }^{\text {Tyr }}$, pTYR was linearized with BstNI and transcribed with phage T3 RNA polymerase. Following transcription, the DNA template was digested with DNase I (Pharmacia LKB Biotechnology, Inc., Piscataway, NJ; 5 units for $5 \mathrm{~min}$ at $37^{\circ} \mathrm{C}$ ) and subjected to two cycles of extraction with phenol-CIA /phenol/chloroform/isoamyl alcohol, $25: 24: 1)$ and ethanol precipitation. The RNA pellet was then dissolved in $300 \mu \mathrm{l}$ of $10 \mathrm{mM}$ Tris- $\mathrm{HCl}(\mathrm{pH} 7.5)$ and $1 \mathrm{~mm}$ EDTA, and $\sim 1 \mathrm{mg}$ of dissolved RNA was loaded on a DEAESephacel column $(0.7 \times 4-\mathrm{cm}$ column; $0.6-\mathrm{ml}$ bed volume), which had been equilibrated with $50 \mathrm{~mm} \mathrm{NaCl}, 10 \mathrm{~mm}$ Tris- $\mathrm{HCl}$ (pH 7.5), and $1 \mathrm{~mm}$ EDTA (room temperature). The column was washed with $250 \mathrm{~mm} \mathrm{NaCl}, 10 \mathrm{~mm}$ Tris- $\mathrm{HCl}(\mathrm{pH} 7.5)$, and $1 \mathrm{~mm}$ EDTA, and the tRNA was eluted with $800 \mathrm{~mm} \mathrm{NaCl}, 10 \mathrm{~mm}$ Tris- $\mathrm{HCl}(\mathrm{pH} 7.5)$, and $1 \mathrm{~mm}$ EDTA. The eluted tRNA was precipitated with ethanol and redissolved in $10 \mathrm{mM}$ Tris- $\mathrm{HCl} / \mathrm{pH}$ 7.51, 1 mM EDTA.

The in vitro tRNA ${ }^{\text {Tyr }}$ transcript is recognized efficiently by CYT-18 protein. In parallel experiments with the same CYT-18 protein preparation, the $K_{\mathrm{m}}$ value for the in vitro-synthesized Neurospora mt tRNA ${ }^{\mathrm{Tyr}}$ was $7 \pm 3 \mu \mathrm{M}$ compared with $25 \pm 6$ $\mu \mathrm{M}$ for $E$. coli tRNA ${ }^{\mathrm{Tyr}}$, and the $V_{\max }$ was about half that for the E. coli tRNA ${ }^{\text {Tyr }}$ (Cherniack et al. 1990; Cherniack 1991; Kittle et al. 1991).

E. coli $\mathrm{tRNA}^{\text {Phe }}$ and yeast tRNA ${ }^{\text {Phe }}$ were transcribed from plasmids p67CF0 and p67YF0 (provided by Dr. Olke Uhlenbeck, University of Colorado, Boulder). The plasmids were digested with BstNI and transcribed with phage T7 RNA polymerase (Sampson and Uhlenbeck 1988). The resulting tRNA transcripts were purified as described above for the Neurospora $\mathrm{mt}$ tRNA $^{\text {Tyr }}$ transcript.

\section{Isolation of mitochondrial RNA and mt RNP particles}

Mitochondria were purified by the flotation gradient method (Lambowitz 1979). Mitochondrial RNA was extracted by the SDS-urea plus phenol-CIA procedure (Garriga et al. 1984). RNP particles were isolated by lysing mitochondria with $1 \%$ Nonidet P-40, followed by centrifugation of the lysate through a 1.85 $\mathrm{M}$ sucrose cushion containing $0.5 \mathrm{M} \mathrm{KCl}$ buffer (Akins and Lambowitz 1987).

\section{Preparation of CYT-18 protein from Neurospora and E. coli}

CYT-18 protein was obtained from mitochondrial RNPs of Neurospora wild-type $74 \mathrm{~A}$ by heparin-Sepharose chromatography (Majumder et al. 1989) or synthesized in E. coli from the expression plasmid pEX560 (Kittle et al. 1991). The E. coli-synthesized CYT-18 protein used for binding assays was purified extensively by using a recently developed procedure involving polyethyleneimine precipitation of nucleic acids, ammonium sulfate fractionation, and chromatography in a CM-Sepharose column ( $R$. Saldanha and A.M. Lambowitz, unpubl.). The final protein fractions were $\sim 95 \%$ pure, with the major impurities being slightly 
smaller proteins that cross-reacted with anti-CYT-18 antibodies.

\section{Synthesis of in vitro transcripts}

In vitro transcripts were synthesized from recombinant plasmids linearized with restriction enzymes, by use of phage T3 or T7 RNA polymerase (Stratagene), essentially as described (Yisraeli and Melton 1989). Following transcription, the DNA template was digested with DNase I (Pharmacia; 5 units for 5 min at $37^{\circ} \mathrm{Cl}$, and the transcript was phenol/CIA-extracted and ethanol-precipitated twice. Standard transcription reactions were carried out in a volume of $200 \mu \mathrm{l}$ with $0.5 \mathrm{~mm}$ rNTPs for $60 \mathrm{~min}$ at $37^{\circ} \mathrm{C}$. To synthesize large amounts of RNAs for competition experiments, transcription was carried out in a volume of $400 \mu \mathrm{l}$ with $2 \mathrm{~mm}$ rNTPs. To synthesize high-specific-activity ${ }^{32} \mathrm{P}$-labeled transcripts for nitrocellulose filter-binding assays, transcription was carried out in a volume of $50 \mu \mathrm{l}$ with $0.4 \mathrm{mM}$ ATP, GTP, and CTP, $0.04 \mathrm{mM}$ UTP, and $150 \mu \mathrm{Ci}$ of $\left[\alpha^{-}{ }^{32} \mathrm{P}\right] \mathrm{UTP}(3000$ $\mathrm{Ci} /$ mmole; NEN-DuPont, Boston, MA). To synthesize ${ }^{32} \mathrm{P}$-labeled transcripts for splicing assays, transcription was carried out in a volume of $50 \mu \mathrm{l}$ with $0.4 \mathrm{mM}$ ATP, GTP, CTP, and UTP plus $150 \mu \mathrm{Ci}\left[\alpha_{-}{ }^{32} \mathrm{P}\right] \mathrm{UTP}(3,000 \mathrm{Ci} / \mathrm{mmole}$; NEN-DuPont $)$.

\section{Nitrocellulose filter-binding assay}

Approximately 5 pM ${ }^{32} \mathrm{P}$-labeled RNA $(18 \mu \mathrm{Ci} / \mathrm{pmole})$ was mixed with different amounts of CYT-18 protein in $500 \mu \mathrm{l}$ of TMK buffer [10 mM Tris- $\mathrm{HCl}(\mathrm{pH} 7.5\rangle, 5 \mathrm{mM} \mathrm{MgCl}_{2}, 100 \mathrm{~mm}$ $\mathrm{KCl}$ ] containing $50 \mu \mathrm{g}$ acetylated bovine serum albumin (New England Biolabs, Inc., Beverly, MA) plus nonspecific competitors $40 \mu \mathrm{g}$ of poly $(\mathrm{rC})$ (Pharmacia) and $10 \mu \mathrm{g}$ of yeast total RNA (Sigma Chemical Co., St. Louis, MO). The samples were incubated for $2 \mathrm{~min}$ at $37^{\circ} \mathrm{C}$, followed by $15 \mathrm{~min}$ at room temperature and placed on ice to await filtration. Control experiments with pBD5A/BanI showed that $K_{\mathrm{d}}$ values at $0^{\circ} \mathrm{C}$ and $25^{\circ} \mathrm{C}$ are essentially the same $(6-7 \mathrm{nM})$ and that the $K_{\mathrm{d}}$ at $37^{\circ} \mathrm{C}$ is $12 \mathrm{~nm}$ (not shown). The values indicated in the text correspond to the $K_{\mathrm{d}}$ at $25^{\circ} \mathrm{C}$. Samples were filtered under gentle vacuum through a nitrocellulose filter (HAWP02500; Millipore Co., Bedford, MA), which had been prewetted with the TMK buffer plus 40 $\mu \mathrm{g} / \mathrm{ml}$ of denatured salmon sperm DNA (Sigma). After filtration, the filters were washed three times with $0.9 \mathrm{ml}$ of TMK buffer plus $40 \mu \mathrm{g} / \mathrm{ml}$ of denatured salmon sperm DNA and dried at $80^{\circ} \mathrm{C}$. Radioactivity retained on the filter was measured by liquid scintillation counting, by use of Ready Protein Liquid Scintillation Cocktail (Beckman Instruments, Inc., Fullerton, CA). Binding data were analyzed as described by Yarus and Berg (1967), with the proportion of active CYT-18 protein $(\sim 60 \%)$ determined by the method of Riggs et al. (1970). The binding of the CYT- 18 protein to the intron-containing transcript was saturated after $1 \mathrm{~min}$ at $37^{\circ} \mathrm{C}$ and was stable for at least $60 \mathrm{~min}$ at $0^{\circ} \mathrm{C}$ or $25^{\circ} \mathrm{C}$.

\section{Assay of tyrosyl-tRNA synthetase activity}

TyrRS activity of the CYT- 18 protein was assayed essentially as described (Akins and Lambowitz 1987). For experiments involving large numbers of samples, TyrRS assays were carried out with CYT-18 protein in micrococcal nuclease-digested mitochondrial RNP preparations from wild-type $74 A$ (Akins and Lambowitz 1987). The use of these preparations circumvents problems owing to instability of TyrRS activity associated with purified mitochondrial CYT-18 protein (Majumder et al. 1989). TyrRS assays were carried out in $20 \mu \mathrm{l}$ of reaction medium containing $50 \mathrm{~mm}$ Tris- $\mathrm{HCl}$ ( $\mathrm{pH} 8.8$ ), $15 \mathrm{~mm} \mathrm{MgCl}_{2}, 5 \mathrm{~mm}$ ATP,
$1 \mu \mathrm{Ci}$ of $\mathrm{L}-\left[3,5-{ }^{3} \mathrm{H}\right]$-tyrosine $(50 \mathrm{Ci} /$ mmole ; Amersham Co., Arlington Heights, IL) and $1 \mu \mathrm{g}$ of tRNA substrate $(1.63 \mu \mathrm{M}$ for Neurospora mt tRNA ${ }^{\mathrm{Tyr}} ; 1.73 \mu \mathrm{M}$ for E. coli $\left.\mathrm{tRNA}^{\mathrm{Tyr}}\right)$. Reactions were initiated by the addition of enzyme preparation, incubated at $30^{\circ} \mathrm{C}$ for $10 \mathrm{~min}$, and terminated by the addition of $0.5 \mathrm{ml}$ of $10 \%$ TCA $-0.1 \%$ SDS. TCA-precipitable radioactivity was collected on Whatman GF/C filters and counted as described previously (Akins and Lambowitz 1987).

\section{Splicing assays}

Splicing reactions with unlabeled precursor RNA were carried out as described (Majumder et al. 1989) in $20 \mu$ l of reaction medium containing $0.5 \mu \mathrm{g}$ of in vitro transcript substrate, $4 \mu \mathrm{l}$ of CYT-18 protein preparation $\{0.8 \mu \mathrm{g}$ of CYT- 18 protein preparation from Neurospora $74 A$ RNPs or $6-30 \mathrm{~nm}$ purified $E$. colisynthesized CYT-18 protein), $100 \mathrm{mM} \mathrm{KCl}, 5 \mathrm{mM} \mathrm{MgCl}_{2}, 20 \mathrm{mM}$ Tris- $\mathrm{HCl}(\mathrm{pH} 7.5), 5 \mathrm{~mm}$ DTT, and $40 \mu \mathrm{Ci}$ of $\left[\alpha^{-}{ }^{32} \mathrm{P}\right] \mathrm{GTP}$ (3000 $\mathrm{Ci} / \mathrm{mmole}$; NEN-DuPont). Reactions were initiated by the addition of the CYT -18 protein, incubated at $37^{\circ} \mathrm{C}$ for $10-30 \mathrm{~min}$, and stopped by the addition of $180 \mu \mathrm{l}$ of $10 \mathrm{~mm}$ Tris $-\mathrm{HCl} / \mathrm{pH}$ 7.5), $5 \mathrm{mM}$ EDTA, $10 \mu \mathrm{g}$ of total E. coli tRNA (Sigma), and 200 $\mu$ l of phenol-CIA. Splicing assays with ${ }^{32}$ p-labeled in vitro transcripts $(\sim 20,000 \mathrm{cpm} ; 2 \mathrm{ng})$ were the same, except that the GTP concentration was $250 \mu \mathrm{M}$ and reactions were incubated for 7 min. After phenol-CIA extraction and ethanol precipitation, samples were analyzed by electrophoresis in a $5 \%$ polyacrylamide gel (20:1 acrylamide/bisacrylamide) containing $8 \mathrm{M}$ urea, $90 \mathrm{~mm}$ Tris, $90 \mathrm{~mm}$ boric acid, and $2.5 \mathrm{~mm}$ EDTA.

\section{Acknowledgments}

We thank Dr. Roland Saldanha for the CYT-18 protein preparation used for nitrocellulose filter-binding assays and Dr. Olke Uhlenbeck for plasmids p67YF0 and p67CF0 and advice on purification of in vitro-synthesized tRNAs. This work was supported by National Institutes of Health grant GM37951.

The publication costs of this article were defrayed in part by payment of page charges. This article must therefore be hereby marked "advertisement" in accordance with 18 USC section 1734 solely to indicate this fact.

\section{References}

Akins, R.A. and A.M. Lambowitz. 1987. A protein required for splicing group I introns in Neurospora mitochondria is mitochondrial tyrosyl-tRNA synthetase or a derivative thereof. Cell 50: 331-345.

Bedouelle, H. 1990. Recognition of tRNA ${ }^{\text {Tyr }}$ by tyrosyl-tRNA synthetase. Biochimie 72: 589-598.

Belfort, M., P.S. Chandry, and J. Pedersen-Lane. 1987. Genetic delineation of functional components of the group I intron in the phage T4 $t d$ gene. Cold Spring Harbor Symp. Quant. Biol. 52: 181-192.

Burger, G. and S. Werner. 1985. The mitochondrial URF1 gene in Neurospora crassa has an intron that contains a novel type of URF. J. Mol. Biol. 186: 231-242.

Cech, T.R. 1990. Self-splicing of group I introns. Annu. Rev. Biochem. 59: 543-568.

Cherniack, A.D. 1991. "Involvement of mitochondrial tyrosyl tRNA synthetase in splicing: Identification of an N-terminal domain that functions in splicing." Ph.D. thesis, The Ohio State University, Columbus, $\mathrm{OH}$.

Cherniack, A.D., G. Garriga, J.D. Kittle Jr., R.A. Akins, and A.M. Lambowitz. 1990. Function of Neurospora mitochon- 
drial tyrosyl-tRNA synthetase in RNA splicing requires an idiosyncratic domain not found in other synthetases. Cell 62: 745-755.

Chu, F.K., G.F. Maley, F. Maley, and M. Belfort. 1984. Intervening sequence in the thymidylate synthase gene of bacteriophage T4. Proc. Natl. Acad. Sci. 81: 3049-3053.

Collins, R.A. and A.M. Lambowitz. 1985. RNA splicing in Neurospora mitochondria. Defective splicing of mitochondrial mRNA precursors in the nuclear mutant cyt18-1. I. Mol. Biol. 184: 413-428.

Darnell, J.E. and W.F. Doolittle. 1986. Speculations on the early course of evolution. Proc. Natl. Acad. Sci. 83: 1271-1275.

Davis, R.H. and F.J. de Serres. 1970. Genetic and microbiological research techniques for Neurospora crassa. Methods Enzymol. 17A: 79-143.

Dib-Haji, S.D. 1990. "In vitro studies of domains 1,3 and 5 of self-splicing group II introns of yeast mtDNA." Ph.D. thesis, The Ohio State University, Columbus, $\mathrm{OH}$.

Dixon, M. and E.C. Webb. 1979. Enzymes, 3rd ed., pp 346-347, Academic Press, New York.

Dock-Bregeon, A.C., E. Westhof, R. Giegé, and D. Moras. 1989. Solution structure of a tRNA with a large variable region: Yeast tRNA $^{\text {Ser }}$. I. Mol. Biol. 206: 707-722.

Dock-Bregeon, A.C., A. Garcia, R. Giegé, and D. Moras. 1990. The contacts of yeast tRNA ${ }^{\text {Ser }}$ with seryl-tRNA synthetase studied by footprinting experiments. Eur. I. Biochem. 188: $283-290$.

Dujon, B. 1980. Sequence of the intron and flanking exons of the mitochondrial 21S rRNA gene of yeast strains having different alleles at the $\omega$ and rib-1 loci. Cell 20: 185-197.

Freifelder, D. 1987. Molecular biology, 2nd ed., Jones and Bartlett Publishers, Boston, MA.

Gampel, A. and T.R. Cech. 1991. Binding of the CBP2 protein to a yeast mitochondrial group I intron requires the catalytic core of the RNA. Genes \& Dev. 5: 1870-1880.

Garriga, G. and A.M. Lambowitz. 1984. RNA splicing in Neurospora mitochondria. Self-splicing of a mitochondrial intron in vitro. Cell 39: 631-641.

- 1986. Protein-dependent splicing of a group I intron in ribonucleoprotein particles and soluble fractions. Cell 46: 669-680.

Garriga, G., H. Bertrand, and A.M. Lambowitz. 1984. RNA splicing in Neurospora mitochondria. Nuclear mutants defective in both splicing and $3^{\prime}$ end synthesis of the large rRNA. Cell 36: 623-634.

Gott, J.M., D.A. Shub, and M. Belfort. 1986. Multiple self-splicing introns in bacteriophage T4: Evidence from autocatalytic GTP labeling of RNA in vitro. Cell 47: 81-87.

Guo, Q. 1992. "Interaction of tyrosyl-tRNA synthetase with group I introns." Ph.D. thesis, The Ohio State University, Columbus, $\mathrm{OH}$.

Guo, Q., R.A. Akins, G. Garriga, and A.M. Lambowitz. 1991. Structural analysis of the Neurospora mitochondrial large rRNA intron and construction of a mini-intron that shows protein-dependent splicing. J. Biol. Chem. 266: 1809-1819.

Heckman, J.E. and U.L. RajBhandary. 1979. Organization of tRNA and rRNA genes in N. crassa mitochondria: Intervening sequence in the large rRNA gene and strand distribution of the RNA genes. Cell 17: 583-595.

Heckman, J.E., B. Alzner-DeWeerd, and U.L. RajBhandary. 1979. Interesting and unusual features in the sequence of Neurospora crassa mitochondrial tyrosine transfer RNA. Proc. Natl. Acad. Sci. 76: 717-721.

Heinen, U. 1991. Mitochondriale genexpression bei pilzen: molekulare analysen zur nukleo-zytoplasmatischen wechselwirkung. Diss. Bot. 166: 50-51.
Heuer, T.S., P.S. Chandry, M. Belfort, D.W. Celander, and T.R. Cech. 1991. Folding of group I introns from bacteriophage T4 involves internalization of the catalytic core. Proc. Natl. Acad. Sci. 88: 11105-11109.

Himeno, H., T. Hasegawa, T. Ueda, K. Watanabe, and $M$. Shimizu. 1990. Conversion of aminoacylation specificity from tRNA ${ }^{\text {Tyr }}$ to tRNA ${ }^{\text {Ser }}$ in vitro. Nucleic Acids Res. 18: 6815-6819.

Jarrell, K.A., R.C. Dietrich, and P.S. Perlman. 1988. Group II intron domain 5 facilitates a trans-splicing reaction. Mol. Cell. Biol. 8: 2361-2366.

Joyce, G.F., G. van der Horst, and T. Inoue. 1989. Catalytic activity is retained in the Tetrahymena group I intron despite removal of the large extension of element P5. Nucleic Acids Res. 17: 7879-7889.

Kämper, U., U. Kück, A.D. Cherniack, and A.M. Lambowitz. 1992. The mitochondrial tyrosyl-tRNA synthetase of Podospora anserina is a bifunctional enzyme active in protein synthesis and RNA splicing. Mol. Cell. Biol. 12: 499-511.

Kittle, J.D., Jr., G. Mohr, J.A. Gianelos, H. Wang, and A.M. Lambowitz. 1991. The Neurospora mitochondrial tyrosyl-tRNA synthetase is sufficient for group I intron splicing in vitro and uses the carboxy-terminal tRNA-binding domain along with other regions. Genes \& Dev. 5: 1009-1021.

Kubelik, A.R., B. Turcq, and A.M. Lambowitz. 1991. The Neurospora crassa cyt-20 gene encodes cytosolic and mitochondrial valyl-tRNA synthetases and may have a second function in addition to protein synthesis. Mol. Cell. Biol. 11: 4022-4035.

Kuiper, M.T.R. and A.M. Lambowitz. 1988. A novel reverse transcriptase activity associated with mitochondrial plasmids of Neurospora. Cell 55: 693-704.

Kunkel, T.A., J.D. Roberts, and R.A. Zakour. 1987. Rapid and efficient site-specific mutagenesis without phenotypic selection. Methods Enzymol. 154: 367-382.

Lambowitz, A.M. 1979. Preparation and analysis of mitochondrial ribosomes. Methods Enzymol. 59: 421-433.

Lambowitz, A.M. and P.S. Perlman. 1990. Involvement of aminoacyl-tRNA synthetases and other proteins in group I and group II intron splicing. Trends Biochem. Sci. 15: 440-444.

Lambowitz, A.M., R.J. LaPolla, and R.A. Collins. 1979. Mitochondrial ribosome assembly in Neurospora: Two-dimensional gel electrophoretic analysis of mitochondrial ribosomal proteins. J. Cell Biol. 82: 17-31.

Majumder, A.L., R.A. Akins, J.G. Wilkinson, R.L. Kelley, A.J. Snook, and A.M. Lambowitz. 1989. Involvement of tyrosyltRNA synthetase in splicing of group I introns in Neurospora crassa mitochondria. Biochemical and immunochemical analyses of splicing activity. Mol. Cell. Biol. 9: 2089-2104.

Michel, F. and E. Westhof. 1990. Modelling of the three-dimensional architecture of group I catalytic introns based on comparative sequence analysis. I. Mol. Biol. 216: 585-610.

Mohr, G. and A.M. Lambowitz. 1991. Integration of a group I intron into a ribosomal RNA sequence promoted by a tyrosyl-tRNA synthetase. Nature 354: 164-167.

Mohr, G., A. Zhang, J.A. Gianelos, M. Belfort, and A.M. Lambowitz. 1992. The Neurospora CYT-18 protein suppresses defects in the phage $\mathrm{T} 4 t d$ intron by stabilizing the catalytically active structure of the intron core. Cell 69: 483-494.

Piccirilli, J.A., T.S. McConnell, A.J. Zaug, H.F. Noller, and T.R. Cech. 1992. Aminoacyl esterase activity of the Tetrahymena ribozyme. Science 256: 1420-1424.

Rich, A. and U.L. RajBhandary. 1976. Transfer RNA: Molecular structure, sequence, and properties. Annu. Rev. Biochem. 45: 805-860.

Riggs, A.D., H. Suzuki, and S. Bourgeois. 1970. lac repressor- 
operator interaction. I. Equilibrium studies. I. Mol. Biol. 48: $67-83$.

Rould, M.A., J.J. Perona, D. Söll, and T.A. Steitz. 1989. Structure of E. coli glutaminyl-tRNA synthetase complexed with tRNA $^{\text {Gln }}$ and ATP at $2.8 \AA$ resolution. Science 246: 11351142.

Sampson, J.R. and O.C. Uhlenbeck. 1988. Biochemical and physical characterization of an unmodified yeast phenylalanine transfer RNA transcribed in vitro. Proc. Natl. Acad. Sci. 85: 1033-1037.

Sanger, F., S. Nicklen, and A.R. Coulson. 1977. DNA sequencing with chain-terminating inhibitors. Proc. Natl. Acad. Sci. 74: 5463-5467.

Schimmel, P. 1987. Aminoacyl tRNA synthetases: General scheme of structure-function relationships in the polypeptides and recognition of transfer RNAs. Annu. Rev. Biochem. 56: 125-158.

1989. Parameters for the molecular recognition of transfer RNAs. Biochemistry 28: 2747-2759.

Schimmel, P.R. and Söll, D. 1979. Aminoacyl-tRNA synthetases: General features and recognition of transfer RNAs. Annu. Rev. Biochem. 48: 601-648.

Shub, D.A., M.-Q. Xu, J.M. Gott, A. Zeeh, and L.D. Wilson. 1987. A family of autocatalytic group I introns in bacteriophage T4. Cold Spring Harbor Symp. Quant. Biol. 52: 193200.

von Ahsen, U., J. Davies, and R. Schroeder. 1991. Antibiotic inhibition of group I ribozyme function. Nature 353: 368370.

Weiner, A.M. and N. Maizels. 1987. tRNA-like structures tag the 3 ' ends of genomic RNA molecules for replication: Implications for the origin of protein synthesis. Proc. Natl. Acad. Sci. 84: 7383-7387.

Yarus, M. 1988. A specific amino acid binding site composed of RNA. Science 240: 1751-1758.

Yarus, M. and P. Berg. 1967. Recognition of tRNA by aminoacyl tRNA synthetases. I. Mol. Biol. 28: 479-490.

Yisraeli, J.K. and D.A. Melton. 1989. Synthesis of long, capped transcripts in vitro by SP6 and T7 RNA polymerases. Methods Enzymol. 180: 42-50.

Zaug, A.J., M.D. Been, and T.R. Cech. 1986. The Tetrahymena ribozyme acts like an RNA restriction endonuclease. Nature 324: 429-433. 


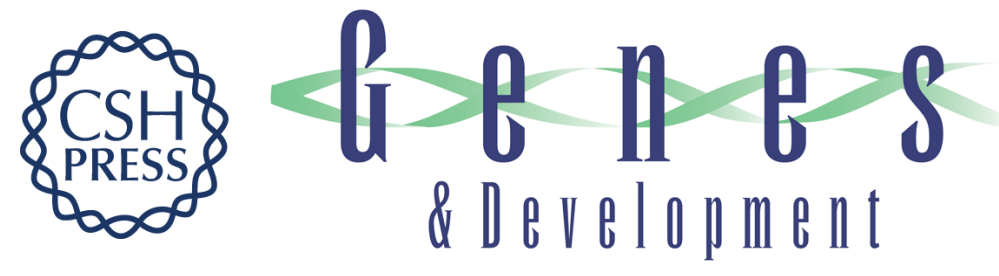

\section{A tyrosyl-tRNA synthetase binds specifically to the group I intron catalytic core.}

Q Guo and A M Lambowitz

Genes Dev. 1992, 6:

Access the most recent version at doi:10.1101/gad.6.8.1357

References This article cites 54 articles, 20 of which can be accessed free at: http://genesdev.cshlp.org/content/6/8/1357.full.html\#ref-list-1

License

Email Alerting Service right corner of the article or click here.

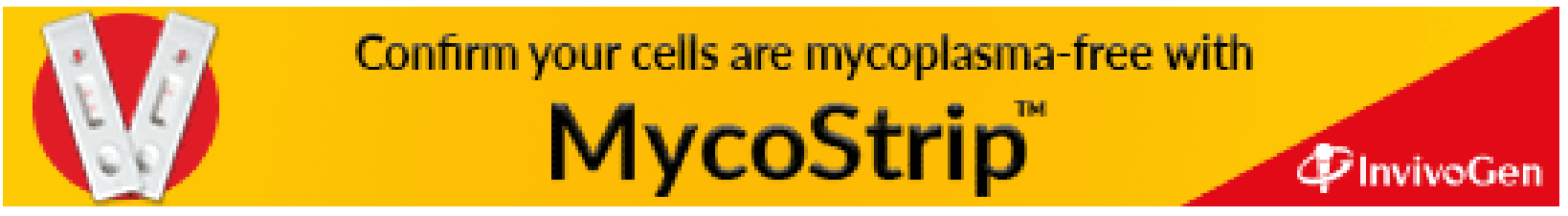

